\title{
THE POLYVOCALITY IN ACTION: EMBODYING THE EPIPHANY ON PUBLIC HOUSING CONUNDRUM
}

\author{
Resi Ariyasa Qadri ${ }^{1^{*}}$, Amrie Firmansyah ${ }^{2}$ \\ $1^{1 * 2}$ Lecturer, Polytechnic of State Finance STAN, Indonesia. \\ Email: *resi.ariyasa@pknstan.ac.id
}

\author{
Article History: Received on $18^{\text {th }}$ June 2020 , Revised on $22^{\text {nd }}$ August 2020 , Published on $27^{\text {th }}$ September 2020
}

\begin{abstract}
Purpose of the study: This paper aims to elaborate on how the institutional logic of public housing provision transforms from the old logic into the new logic. By encapsulating tacit-knowledge from the shift, this study focuses on how to explicate a model of multi-criteria decision-making for executing official residence projects in Indonesia. This research also aims to recuperate the future of the public residency field.
\end{abstract}

Methodology: The methodology employed was a mixed method. The qualitative method was firstly applied by utilizing semi-structured interviews to build a decision-making model. Later, a quantitative method was implemented to improve the consistency of the model by using the Analytical Hierarchy Process protocols. Thirteen project representatives and ten decision-makers were being involved as the main informants. Google Sheets web-based software was applied for analyzing survey results by making use of a mathematical model for the Analytical Hierarchy Process.

Main Findings: The result indicates that land not used as paddy field, fair house price, safe from flood location, serene ambiance, and developer experience has played a significant part in affecting buying decisions for residency projects. To carry out the new method, the total scores of the AHP calculation should be above 50. Otherwise, the government shall opt for the old mechanism.

Applications of this study: The paper contributes to the public sector accounting field in the area of asset management and public housing procurement. The paper also gives a strong basis for the field to make use of the model of Indonesia's public housing provision. The government can adopt the research framework for choosing the new model or the old one.

Novelty/Originality of this study: This study might be the only one of its kind. The research was using a multi-method to achieve the objectives. To generate a multi-criteria decision-making model, grounded data of excessive interviews were abstracted. Then the abstracted tacit-knowledge was tested with AHP to provide a consistent model.

Keywords: Assets Management, Analytic Hierarchy Process, Indonesia, Public Housing, Public Sector Accounting.

\section{INTRODUCTION}

Under President Jokowi's administration, the government of Indonesia has intensively conducted massive development in infrastructure (Negara, 2016; Warburton, 2016). Government infrastructure projects are designed to meet the socioeconomic needs of developing countries (Ahsan \& Gunawan, 2010). Figure 1 shows that half of the government's total projects are construction projects. In this case, those projects comprise road expansion, building arrangement, and house provision $^{1}$. To realize the projects, the government has to carry out the public procurement mechanism based on the related regulation $^{2}$ (Ray \& Ing, 2016; Zukhrina-Oktaviani, 2015). Being involved in the praxis of the public sector area makes us ${ }^{3}$ witnessed that over the past four years, the realization of the construction projects has been exhibiting a positive signal. It indicates that the country's economic growth is on track (Kaming, Olomolaiye, Holt, \& Harris, 1997). However, of all government construction projects, especially those handled by the Ministry of Public Works and Housing (PUPR), the government encounters recurring predicaments, namely cost and time overruns, especially relating to the completion of housing projects (Table 1). Fortunately, the government is not alone in this regard because other developing countries are dealing with the same problems too, such as Southeast Asians: Malaysia (Chai \& Yusof, 2015), Thailand (Toor \& Ogunlana, 2008), Cambodia (Durdyev, Omarov, \& Ismail, 2017), and Singapore (Hwang, Zhao, \& Ng, 2013); East Asians: India (Prasad, Vasugi, Venkatesan, \& Bhat, 2019), and Pakistan (Gardezi, Manarvi, \& Gardezi, 2014). Delay in construction projects becomes a vexatious matter in several developed countries like Nothern Ireland (McCord, McCord, Davis, Haran, \& Rodgers, 2015), and Australia (Walker \& Vines, 2000).

Table 1 exposes a critical issue. The low completion rates on housing projects happen to be a burden in achieving the most challenging target of the "Nawa Cita": providing houses to the society, particularly officials and low-income citizens. However, the essential discourse in the public sector field is to discover a solution for handling the recurring problem of time overrun in housing projects (Arnaboldi, Lapsley, \& Steccolini, 2015). Then, the next question is that "is there one appropriate solution to minimize the time overrun that has been a major obstacle in housing projects for

\footnotetext{
${ }^{1}$ Ministry of Public Works and Housing, Performance Report of The Ministry of Public Works and Houses Year 2018, Page. 10 .

${ }^{2}$ President of Republic Indonesia Decree Number 16/2018 on Public Procurement of Goods and Services.

${ }^{3}$ Using "Me" as the first person pronoun delineates the ontological belief employed (Kamayanti, 2016). 
years?" To answer the question is the sole objective of this research. The public construction project in Indonesia mainly consists of two phases: the procurement phase and contract execution phase (Astadi, Sutarja, \& Nadiasa, 2015). The latter is the phase the government difficult to control because there are plentiful peculiarities involved in the stage (Zidane \& Andersen, 2018).

Nevertheless, the government of Indonesia should mitigate the risk related to and control the procurement phase (Susilawati \& Wirahadikusumah, 2006). The phase can be managed by reducing the duration of the procurement process without lessening the quality (Humphreys, Lo, \& McIvor, 2000). Only when implementing e-procurement will the quality of the process performance improve (Smart, 2010). The public project managers can easily save more time via eprocurement (Hung, Lin, Tai, Ho, \& Jou, 2014). Nevertheless, it only complies with one of 4 methods of official residential provision in Indonesia, namely, build method (Ashaf \& Hidayat, 2019; Qadri, 2019).

Meanwhile, the regulation on housing procurement ${ }^{4}$ offers three different methods other than build mechanism. Those are swap, grant, and buy-directly-from-developer (Ashaf \& Hidayat, 2019). Mostly, the public project managers implemented the build mechanism towards the execution of residency projects ${ }^{5}$ (Qadri, 2019). Based on our 14 years of experience in the construction project management field, four months are the average duration to complete the procurement process of build mechanism. So, can you imagine? If the government presupposes one year for the public project managers to complete the housing project from the procurement phase to project execution phase, then the procurement process only will contribute the major part of the total time length (Hung, Lin, Tai, Ho, \& Jou, 2014; Qadri, 2019). Thus, to answer whether there is a way to minimize the schedule extension that has been the main impediment in the residence project management field for years, the mechanism of buy-directly-from-developer can be the best solution (Qadri, Gunawan, \& Zikrulah, 2020). President of Republic Indonesia Decree Number 11/2008 on State Housing Procurement and Management provides the government a legitimation for using the direct buying mechanism in housing projects (Udoyono, 2012). Alas, there are no government institutions that have performed the mechanism yet, ${ }^{6}$ even though by regulation, it is permissible (Ahsan \& Gunawan, 2010; Qadri, 2019). Implementing the method of buydirectly-from-developer requires the government to develop the basic criteria since they have been stipulated yet, neither in the housing regulation ${ }^{7}$ nor in the general procurement regulation ${ }^{8}$ (Ashaf \& Hidayat, 2019; Qadri, Gunawan, \& Zikrulah, 2020). The criteria have to be obvious and not causing misinterpretation so that the government can decide whether a project shall be carried out by build mechanism or direct buying method (Czischke, 2009; Czischke \& van Bortel, 2018). This study aims to fill in the regulation gap to aid the government in developing the multi-criteria of make-or-buy decisions for residency projects.

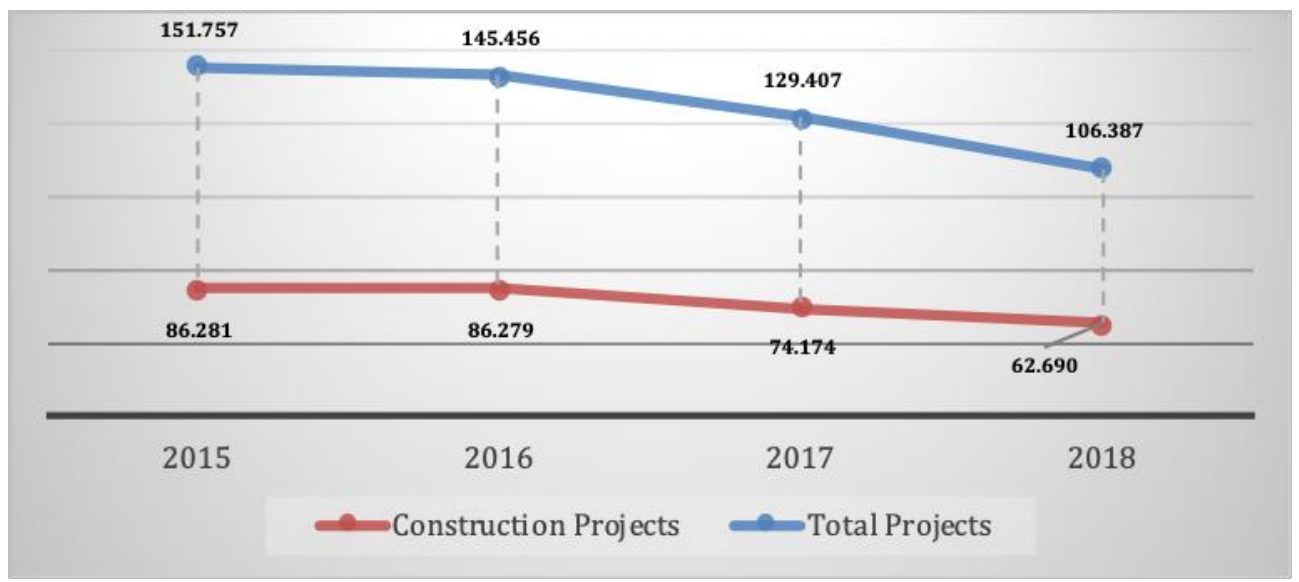

Figure 1: Public Infrastructure Projects in Indonesia

Source: Government Procurement Plan Period 2015-2018

Table 1: Project Completion of Housing Provision

\begin{tabular}{ccccc}
\hline Year & $\begin{array}{c}\text { Total Construction } \\
\text { Projects }\end{array}$ & $\begin{array}{c}\text { House Provision } \\
\text { Target } \\
\text { (In Unit) }\end{array}$ & $\begin{array}{c}\text { House Provision } \\
\text { Completed } \\
\text { (In Unit) }\end{array}$ & $\begin{array}{c}\% \\
\text { Completion }\end{array}$ \\
\hline 2015 & 86.281 & 67.922 & 67.922 & $100 \%$ \\
\hline
\end{tabular}

\footnotetext{
${ }^{4}$ President of Republic Indonesia Decree Number 11/2008 on State Housing Procurement and Management jo. National Procurement Office Regulation Number 12/2018 on The Exception of Public Procurement.

${ }^{5}$ Workshop on Official Housing Project Year 2019 held in the Head Office of Ministry of Finance on January 29, 2019.

${ }^{6}$ Ibid.

${ }^{7}$ Loc.cit. Number 4.

${ }^{8}$ Loc.cit. Number 2.
} 


\begin{tabular}{lllll}
\hline 2016 & 86.279 & 109.601 & 41.679 & $38 \%$ \\
\hline 2017 & 71.174 & 147.165 & 37.564 & $26 \%$ \\
\hline 2018 & 62.690 & 199.765 & 52.600 & $26 \%$ \\
\hline
\end{tabular}

Source: Performance Report of Ministry of Public Works and Housing Year 2018

The decision-making process entangles the appraisal of a multitude of both qualitative and quantitative judgments, including the assessment of a compound set of the interplay between these elements (Ball \& Srinivasan, 1994). There is a scant amount of studies providing a framework for make-or-buy decisions (Sillanpää, 2015), even more in the public housing area (Palm, 2016). Serrano, Ramirez, and Gascó (2018) found that managers often face difficulties in the case of make-or-buy decisions. It becomes a strategic proposition, yet rhetorical. Hwang, Ko, and Goan (2007) faced a typical issue with the make-or-buy decision model in the field of cellular manufacturing and generated a multi-criteria model to help to fill in the void. McIvor, Humphreys, and McAleer (1997) attempted to unravel a panacea model for solving problems emanating from the make-or-buy decision in the private sector. Culled from a case study in a global telecommunications equipment company and its suppliers for the last ten years from the year 2000, Humphreys, Lo, McIvor (2000) uncovered make-or-buy decision problems affecting the profit margin of the company. In the meantime, Tayles and Drury (2001) buttressed with Sillanpää (2015) proposed a framework for the make-or-buy decision-making process. In sum, rather than creating the make-or-buy decision-making framework for improving the governance in public sector organizations, most of the previous studies played their roles by generating a framework to improve the supply chain efficiency and boost the profit margin in private sector companies.

On the contrary to previous studies, our study focuses on filling the research gap in the public housing field. Our research attempts to improve government judgment in the make-or-buy decision-making process, especially in the area of public housing since there is a scant amount of literature discussing the decision-making model for the public sector field. Therefore, the purpose of this study encapsulated succinctly from described phenomena, problems aroused, and praxis-research gaps is to answer three main research questions. They are (1) how far are the actors' roles in the Ministry of Finance in shifting the organizational logic in the public housing field in Indonesia? (2) how should the model of multi-criteria decision-making be befitted for public housing provision? (3) how should the future of public residency procurement be looked like?

To answer the first research question, we carried out the qualitative research method. However, the result of qualitative method employment in developing decision-making criteria always raises a common issue (Ball \& Srinivasan, 1994). The assessment of qualitative criteria is naturally judgmental so that the major issue emerges and deserves attention is the aptitude to extricate consistent decisions (Ball \& Srinivasan, 1994). To address the issue of inconsistency related to the qualitative criteria of the make-or-buy decision-making model, we employed the Analytic Hierarchy Process (AHP) that is widely applied for developing the consistency of a multi-criteria decision-making model (Saaty, 2004). Implementing the quantitative method of AHP is important to answer the remaining research questions. Then, we conducted the study at the mezzo level: the Ministry of Finance of Indonesia (MOF). The sole reason is that the MOF was appointed as the pilot project for developing and implementing the model of the make-or-buy decision in the sector of official residency in Indonesia ${ }^{9}$ (Qadri, 2019; Qadri et al., 2020). Nevertheless, the results of this study are still relevant to other government institutions for being adopted in their housing projects because every government institution has the same regulatory framework ${ }^{10}$ (Qadri, 2019; Udoyono, 2012).

Subsequently, the results of our study can be used as a basis for further research at the macro level using the nation-wide survey to develop a generic model in public housing policy for the government of Indonesia as well as other developing country governments that have a similar setting.

\section{LITERATURE REVIEW}

\section{Meta-theoretical Framework of Public Housing: Providing Homogeneous Residency for Government Officials}

Ruonavaara provoked an interesting discourse: "there is no theory of housing, but a meta-theoretical framework for various kinds of problem-solving analyses of housing procurement" (2018). His statement becomes a prominent proposition in the housing field of study, especially in the area of the public sector field (Kimhur, 2020). He adds another insightful discourse: "residency is a rather multi-faced theme" (Ruonavaara, 2018). Interestingly, Wang (2012) expressed approval to his proposition: "to provide public housing is to minimize differences in the built environment regarding location, physical quality, and size of the residence." He further explained that the most prominent characteristic of public housing projects is "the housing landscape was strictly regulated by a series of planning and building design guidelines" (2012).

Meanwhile, the objectives of the official residence program are to meet the necessities of basic shelter, to create the stability of living cost in the local area, to maintain the social stability, and to increase the integration of society as a

\footnotetext{
${ }^{9}$ Official Memo of LKPP to MOF on Guidance for Developing the Procedures of Buy-From-Developer.

${ }^{10}$ Loc.cit. Number 4.
} 
whole (Field, 1987; Teo, 2015). In the context of Indonesia, the government defines public housing as: "a building that is owned by the state and functions as a residence for officials and a means to foster their family and support the settlement of their duties." 11 From this definition, two basic understandings are conforming with what Rohe (1995) specifies as the cooperative housing: first, the house is owned and managed by the government; second, the residents, who are officials and their family, are free to utilize the house by their duties and functions (Miceli, Sazama, \& Sirmans, 1994; Rohe, 1995).

In this case, the primary hurdle confronted by the government is that the former residents deny to handover their usufructuary rights to the new residents (Lang \& Novy, 2014). The formers are usually reluctant to be supplanted because they have lived in for age (Bockman, 2018). In the United States, there is a "prescription" often used to treat the reluctance of the old occupants who are misdirected in claiming a statehouse that is not theirs, namely: undertake a major renovation to the house, so that inevitably the old residents will shift to another dwelling. Thus their most notable claim to power will be deprived, specifically: their body inside the house (Bockman, 2018). Furthermore, Walker (2001) provoked an indigenous formula to overcome the reluctance problem of former residents, that is transfer the house management rights to the private party, limit all resources supplying the needs of the old inhabitants, isolate them from the surrounding environment, then as time goes by, the house will destroy its dwellers.

\section{Previous Researches on Housing: Unveiling the Criteria of Make-or-Buy Decision in Residency Projects}

A number of studies suggest that the most influential drivers in make-or-buy property decisions are physical quality problems and budget-related issues (Moschuris, 2007). Sillanpää (2015) argues that project managers decide to execute a buying decision because of the budget threshold problem, lack of knowledge, and lack of resources. "The trend of buying property, instead of making it, is bound to several reasons," said Mantel, Tatikonda, and Liao (2006). Those reasons are related to quality issues: "competent developers as well as good suppliers supervision" (Chauhan, Shah, \& Rao, 2008; Hwang, Ko, \& Goan, 2007; Mantel, Tatikonda, \& Liao, 2006; Sun, Pan, Wang, \& Zhang, 2013), and cost efficiency problems: "mitigating the exposure of risk along with decreasing the cost" (Cheng, Li, \& Yu, 2005; Mantel et al., 2006; Prajanti, 2014). When project managers decide to execute a buying decision, they have to be cautious about the opportunistic behaviors of the suppliers (Duarte, Souza, Macau, \& Souza, 2017). According to Duarte, Souza, Macau, and Souza (2017), the risk related to opportunistic behaviors will cause increased prices of properties. To tackle the risk, Villena, Revilla, and Choi (2011) suggest the project managers in the public housing field to "invite international suppliers to compete with the local ones in order to exert the locals to decrease their margins." By reducing the profit on property prices, the local suppliers can maintain their market shares against international competitors (McIvor, 2003).

Basically, there are several strategies to deal with the ubiquity of opportunism (McIvor, 2008). All of them are related to supplier credibility (Gerbl, McIvor, \& Humphreys, 2016; Handley \& Benton, 2012; Humphreys et al., 2000; McIvor, Humphreys, \& McAleer, 1997). The first strategy is that organizations have to withstand the process of creating properties internally (Gerbl et al., 2016). In this case, the project managers should set aside the vendor credibility and exercise the decision to make houses utilizing every resource they have (Sun et al., 2013). In contrast to the first strategy, the next strategy is suggested by Marshall, Ambrose, McIvor, and Lamming (2015). The strategy focuses attention on strengthening the buying strategy, especially the vendor credibility (Ashaf \& Hidayat, 2019; Cheng et al., 2005; Ho, Newell, \& Walker, 2005). To fight against the opportunism, they recommend the project managers to "establish a relational contract arrangement which encourages flexibility and a solution to resolving vexatious matters together" (Marshall et al., 2015). Otherwise, companies should simplify the complexity of the buying strategy by fractionalizing it into smaller processes that could be supplied by several vendors (Gunasekaran, Subramanian, \& Rahman, 2015; Nilsson, 2019). "In turn, those [smaller fractionalized] processes will lower the uncertainty level in the transaction," McIvor (2008) explained. Furthermore, he proposed that "by minimizing the uncertainty level, the opportunistic behavior effect will be minimized too" (McIvor, 2016). His proposition amplified what Handley and Benton (2012) have sounded in their study on supplier opportunism.

We discovered that supplier credibility, budget sufficiency, and physical quality were come off second-best to the other salient factors in influencing the make-or-buy decision, especially those associating with the decision to buy a property. Those factors are (1) the community facilities (Ball \& Srinivasan, 1994; Cheng et al., 2005; Ho et al., 2005; Johnson, 2001; Wu, 2010; Yap, Ho, \& Ting, 2019), (2) the site location preference (Ashaf \& Hidayat, 2019; Deveci, Akyurt, \& Yavuz, 2018; Erbıyı, Özcan, \& Karaboğa, 2012; Ismail \& Shaari, 2019; Kuo, Chi, \& Kao, 2002; Roig-Tierno, BavieraPuig, Buitrago-Vera, \& Mas-Verdu, 2013; Stringfellow, Teagarden, \& Nie, 2008; Takamura \& Tone, 2003), (3) the living environment (Ball \& Srinivasan, 1994; Bender, Din, Hoesli, \& Brocher, 2000; Grum \& Kobal-Grum, 2015; Ismail \& Shaari, 2019; Kuzman, Grošelj, Ayrilmis, \& Zbašnik-Senegačnik, 2013; Thaker \& Sakaran, 2016). There is a dearth of studies in the housing field, examining the importance of community facilities in affecting the decision to buy a house (Qadri, 2019). The groundbreaking research by Ball and Srinivasan (1994) explicates that community facilities like school quality, government amenity, and social entertainment play a pivotal role in the buying decision. Johnson's (2001) study supports Ball and Srinivasan's (1994) research by establishing a savvy finding that community facilities have

\footnotetext{
${ }^{11}$ Ibid.
} 
moderate dominance over the house location. Other scholars append that the combination of community facilities and neighborhood are the two most influential factors in house selection using the AHP (Wu, 2010; Yap et al., 2019).

However, project managers in the housing field are to an increasing extent becoming fully aware that site location preference and living environment should not be ignored in deciding the option to make or buy a property (Ismail \& Shaari, 2019; Qadri et al., 2020; Thaker \& Sakaran, 2016). The shorter the dwelling distance to the workplace, the shorter is the consideration to buy the residence (Ismail \& Shaari, 2019). "Specifically, male workers tend to select the house location as the main desirability of dwelling decision," Ismail and Shaari (2019) added. Research on Indonesian home buyers' behavior by Ashaf and Hidayat (2019) reveals that homebuyers in Indonesia rate highly on location more than pure price saving. The same preference applies to Hungarian home buyers, as explained by Kauko (2006, 2007) that "For the first time, residence buyers place the location as the top priority. At the time when moving forward to the second buy, the location loses its dominance to house quality.

Nevertheless, if you want to execute the buy decision, then you should not neglect the influence of the living environment (Qadri, 2019; Wu, 2010; Yap et al., 2019). Under certain circumstances, the living environment, like public transportation access and the level of safety dwellers perceived, takes the lead in the pursuit of finding a suitable house as stated by Wu (2010): "Pleasant living neighborhood gauged by good public traffic network and a high degree of safety is amongst top clinchers in dwelling consumption in China." His finding bolsters Bender, Din, Hoesli, and Bocher's (2000) study that high quality of the living environment, in the form of high quietness level, provides more attraction to dwelling buyers in Geneva, Switzerland. Furthermore, a strong sense of neighborhood among dwellers in a community can foster a strong bond in the living environment $(\mathrm{Li}, 2008)$. Thus, the sense of neighborhood is one of the most important factors in defining the living environment (Grum, 2017).

\section{METHODOLOGY}

We employed a mixed-method in conducting the research. We used the combination of the qualitative and quantitative approaches to develop the multi-criteria decision-making model of housing provision. We embraced the abstractionistnarrative paradigm developed by Boje (Boje, 2019; Rosile, Boje, Carlon, Downs, \& Saylors, 2013). Boje (2019) raises three philosophical questions regarding the use of his paradigm: "what is the nature of being-in-the-world?" (ontology); "does the researcher intend to unravel existing reality through the story or develop a change in dominant reality?" (epistemology); "how does the researcher intend to use data that are gathered from stories?" (methodology). Rosile firmly argues that the researcher should iteratively ask himself to answer the questions in order to: "create robustly, and rigorous storytelling research that matches ontological and epistemological assumptions with appropriate methods" (2013, p. 12). Responding to Rosile's argument, we viewed the nature of being-in-the-world as constituting reality. Therewithal one of the goals of our study was to construct a change in the reality of the public procurement field, specifically in the area of public housing provision.

The paradigm of abstractionist-narrative is built on the basic assumption that the researcher is in the necessity of abstract concepts for utilization in the upcoming generalized study (Rosile, Boje, Carlon, Downs, \& Saylors, 2013). Overlying on this assumption, the paradigm epistemology that should be implemented is (1) to discover for linguistic schemes, and then (2) to abstract them into the transcendent level of knowledge (Rosile et al., 2013). This epistemology notifies a methodological purpose in extracting what has been uncovered (Heracleous \& Barrett, 2001). The reason of why we used a set of Boje paradigm and epistemology was that the nature of our research was aligning with what Rosile suggested that if a study is intended to alter sets of action, at that point exploiting Boje set of paradigm and epistemology is highly preferable (2013, p. 10).

The method to uncover linguistic schemes was gained by implementing the Boje qualitative method of storytelling organization (Boje, 1995, 2019). Aligning the method with the set of paradigm and epistemology proposed by Boje was mandatory for setting the tone of the paper and adjusted it with the paradigm-epistemology (Boje, Rosile, Durant, \& Luhman, 2004). Meanwhile, the method to abstract the schemes into the transcendent level of knowledge was achieved by studying multiple discourses that can uncover significant elements affecting change using the analytic hierarchy process (Saaty, 1982, 2004). The quantitative method of AHP was applied to build a consistent set of criteria that can be utilized over a phenomenon with theoretically typical contextual measurements (Ball \& Srinivasan, 1994; Rosile et al., 2013; Saaty, 2004).

We utilized the combination of a qualitative and quantitative method to develop the multi-criteria decision-making model in the public housing field. This research followed the mixed method procedures suggested by Boje (2019), Saaty (1990), and Saunders (2015) for executing the research steps of data collection and findings analysis. The data collection and analysis steps were embedded in three important stages of the research method, namely (1) stage of gathering terse stories in the Ministry of Finance of Indonesia, (2) stage of conducting a systematic review on the house provision field, and (3) stage of implementing the AHP. We made use of the data collection and analysis for the qualitative method of the Boje storytelling organization framework in the first two-stage (Boje, 1991, 2019). After that, in the last stage, we implemented the data collection and analysis for the quantitative method of the AHP (Saaty, 1982, 1990). 


\section{Stage 1: Gathering Terse Stories in MOF}

We started our research by carrying out the participatory observation at the beginning of January 2019 at the head office of the Ministry of Finance until July 2019. We devoted our time to attend several meetings that discussed the residency provision. We took some field notes and actively participated in some conversations between colleagues in the office. We gathered stories from project managers, procurement committee, and vendors by recording and transcribing every important meeting. In general, we have outlined four of great importance events for depicting the stories of public housing perplexity. Those events were (1) meeting with National Asset Management Office (DJKN) on January 18th, 2019; (2) meeting with MOF's Internal Auditor Office on January 25th, 2019; (3) workshop on Public Housing Procurement with PUPR on January 29th, 2019; and (4) meeting with LKPP on February 13th, 2019. Eventually, we condensed the storied discourses and put them chronologically in a memo. Afterward, we examined them with thematic analysis techniques. We opined that stories, in the MOF head office, were not simply something which individuals advise to others to engage, nor simply something they do when they impart. Rather, stories are the veins through which changes throb in the core of MOF life.

\section{Stage 2: Conducting Systematic Review on House Provision Field}

Along with our observation, we performed a systematic review to assemble the best practice puzzles in the field of residence provision (Grum \& Kobal Grum, 2015). We searched for articles concerning the field to refine the storied narrative from our observation. We opted for Emerald, JSTOR, Science Direct, and Google Scholars as the publication places for identifying relevant works. We set 20 years: 1999 to 2019 as the period of the systematic review. Then we picked several keywords, namely house selection, site location, store location, and analytic hierarchy process, as the foundation of our searching. We entered those keywords interchangeably into the publication places. Finally, we discovered 346 articles discussing the housing provision, but only 30 articles were relevant to the storied narrative. The results of the systematic review substantiated the stories we collected during our observation. We developed the preliminary criteria and sub-criteria for the inputs of the following stage.

\section{Stage 3: Implementing The AHP}

We employed the AHP to sharpen the judgment and generate consistent decisions (Ball \& Srinivasan, 1994; Schniederjans, Hoffman, \& Sirmans, 1995) for the government, especially MOF on residence provision cases. The AHP was developed by Saaty $(1977,1982)$ on the principles of trade-off and empowered the decision-makers to improve the trade-off verifiably through organizing and scrutinizing a set of mutual pairwise comparison matrices (Ball \& Srinivasan, 1994). The AHP can help decision-makers in attaining a consensus over critical criteria. Even though there is always an opposition against the consensus, decision-makers can still pay more attention to these areas of disagreement to reach the consensus (Ball \& Srinivasan, 1994).

In conducting the AHP procedures, we tested the primary criteria and sub-criteria resulting from storied narrative and systematic review by conducting the preliminary survey to 13 project representatives. Of those participants, ten persons only have given relevant answers. Afterward, we continued the AHP procedures by conducting an extended survey based on a 9-point scale measurement to ten strategic project decision-makers, but we excluded three of them because they lack the experience to understand the survey questions. The main reason why we chose a small sample in the form of ten strategic project decision-makers was based on their expertise consideration. The same reason is expressed by Lai, Wong, and Cheung (2002) as well as Russo and Camanho (2015). Their arguments are supported by the founder of the AHP, Saaty $(1990,2004)$, who argued that the AHP could be executed with small numbers of respondents who have the expertise to cause minor errors in judgment.

The project decision-makers involved in this research had an average of five years of construction project experience. The participants were provided with a background of the first and second surveys, problems in multi-criteria decision making, and a brief explanation about the AHP method. We required the participants to answer the AHP based questionnaire carefully as they had to prioritize their answers first before they filled in the questionnaire. We conducted a meeting with a majority of participants to build a consensus about decision-making problems using the AHP. We gave a chance for the participants to evaluate and revise their answers. The final answer became the input for the AHP procedures of analysis to compose the final model of the multi-criteria decision-making model for public housing provision in Indonesia. To achieve the consistency matrix of the final model, we tersely summed up the AHP procedures into six primary steps (Table 2).

Table 2: The AHP Procedures

\begin{tabular}{ll}
\hline STEP 1 & Decomposition \\
\hline & $\begin{array}{l}\text { We structured major problems into a hierarchy. Every level of hierarchy comprises of a series of } \\
\text { criteria. Then we divide each criterion into sub-criteria for the next level of the hierarchy. The last } \\
\text { level consists of special measures that are going to be executed. }\end{array}$ \\
\hline STEP 2 & Weighting Pairwise Comparison \\
\hline & The 9-points scale measurements adopted from Ball and Srinivasan (1994) show the level of
\end{tabular}


importance between two choices of activities. The measurements are as follows:

One means equal importance or two activities contribute equally to the objective.

3 means weak importance of one over another or experience and judgment slightly favor one activity over another.

5 means moderate importance or experience, and judgment strongly favors one activity over another.

7 means strong importance or activity is strongly favored, and its dominance is demonstrated in practice.

9 means absolute importance, or the evidence favoring one activity over another is of the highest possible order of affirmation.

2, 4, 6,8 mean intermediate values between two adjacent judgments when compromise is needed.

The measurement results are reciprocal, meaning that if activity $i$ has one of the above nonzero numbers assigned to it when compared with activity $\boldsymbol{j}$, then $\boldsymbol{j}$ has the reciprocal value when compared with $i$.

STEP 3 Composing Pairwise Comparison Matrix (PCM

The PCM shows the extent to which one criterion is dominant against another criterion of the same level. The PCM is presented as follows:

$\boldsymbol{O}=\begin{array}{cccc} & O_{1} & O_{2} & O_{n} \\ O_{1} & w_{1} / w_{1} & w_{1} / w_{2} & w_{1} / w_{n} \\ O_{n} & w_{n} / w_{1} & w_{n} / w_{2} & w_{n} / w_{n}\end{array}$

\begin{tabular}{ll}
\hline STEP 4 & Measuring Priority Vector Normalization \\
\hline & $\begin{array}{l}\text { We measured the vector normalization by summing each number in the same column of PCM, then } \\
\text { dividing each number with the total sum, after that summing the result of the division in each row } \\
\text { to determine the geometric mean of the row. }\end{array}$ \\
\hline PTEP 5 & $\begin{array}{l}\text { PCM Consistency Test } \\
\text { for each PCM. There are } 7 \text { PCMs for the main criteria and } 24 \text { PCMs for sub-criteria. The } \\
\text { consistency index (CI) and the consistency ratio (CR) is computed with the following formula: }\end{array}$ \\
& $C I=\frac{(\lambda-n)}{(n-1)}$ \\
\hline
\end{tabular}

RI means random index and is measured as follows:

\begin{tabular}{|l|l|l|l|l|l|}
\hline $\mathbf{n}$ & $\mathbf{R I}$ & $\mathbf{n}$ & $\mathbf{R I}$ & $\mathbf{n}$ & $\mathbf{R I}$ \\
\hline $\mathbf{1}$ & 0,00 & $\mathbf{6}$ & 1,24 & $\mathbf{1 1}$ & 1,51 \\
\hline $\mathbf{2}$ & 0,00 & $\mathbf{7}$ & 1,32 & $\mathbf{1 2}$ & 1,48 \\
\hline $\mathbf{3}$ & 0,58 & $\mathbf{8}$ & 1,41 & $\mathbf{1 3}$ & 1,56 \\
\hline $\mathbf{4}$ & 0,90 & $\mathbf{9}$ & 1,45 & $\mathbf{1 4}$ & 1,57 \\
\hline $\mathbf{5}$ & 1,12 & $\mathbf{1 0}$ & 1,49 & $\mathbf{1 5}$ & 1,59 \\
\hline
\end{tabular}

STEP 6 Formulating Global Weight of Criteria

We synthesize the PCM's priority to create the global weights of multi-criteria decision-making in the field of official house provision.

Source: Adapted from Ball \& Srinivasan $\underline{(1994)}$ and Saaty $(\underline{1977}, \underline{1982})$

\section{RESULTS AND DISCUSSION}

To implement Boje's principles (Boje, 1991), we picture the MOF as the storytelling organization because the MOF has terse stories to tell, the stories of its people undertook a process of enriching the organizational logic of public house provision by developing an indispensable framework of make-or-buy decision. The people took part in a broad type of stakeholder groups, i.e., project managers group in DJKN and MOF Assets Management Centre (Romadan), to march in the procession of information and manage collective memory of the organization, the MOF, utilizing storytelling (Boje, 1991). Old stories of changing organizational logic in housing provision are reminisced in the collective dialogue among stakeholders as they compelled the implementation of the buy-directly-from-developer mechanism, then unfolding stories about composing the framework of make-or-buy decision is created, and future stories on public housing management are shared among stakeholders to make sense of recent dynamics in the organization. 


\section{The First Objective, Precedent Stories: Shifting The Logic of House Provision}

In this section, we describe how the face of the housing provision mechanism in Indonesia is trying to be altered into a new shape. We present the findings and analyses of our study following Boje (1991) style in presenting the results of his study. There are several plots depicted to answer the first objective of this study. Those plots are terse story 1 about the initial trigger of mechanism alteration, terse story 2 about the reason for mechanism change, terse story 3 about raising internal supporters, and terse story 4 about pushing the start button for mechanism shifting.

\begin{tabular}{|c|c|c|}
\hline Hans & $\begin{array}{l}1 . \\
2 . \\
3 . \\
4 .\end{array}$ & $\begin{array}{l}\text { Bro, do me a favor, will you? DJKN has an issue with } \\
\text { their construction projects in their local unit. } \\
\text { They ask us to join the meeting at } 10.00 \text { a.m. in their office. } \\
\text { Just get prepared! }\end{array}$ \\
\hline Ari & $\begin{array}{l}5 . \\
6 .\end{array}$ & $\begin{array}{l}\text { I'm sorry, can I know what the topic we are going to } \\
\text { talk about is? }\end{array}$ \\
\hline Hans & $\begin{array}{l}7 . \\
8 . \\
9 . \\
10 . \\
11 .\end{array}$ & $\begin{array}{l}\text { Sure, I think it is about the official house provision in } \\
\text { West Sulawesi. } \\
\text { Here is the DJKN's notice, learn about it first } \\
\text { before you go there. } \\
\text { Ask Munir or Tedjo with you because I cannot accompany you. }\end{array}$ \\
\hline
\end{tabular}

Figure 2: Terse Story 1 - The Initial Trigger of House Provision Mechanism Change

Source: Adapted from field notes on January 18th, 2019

In Terse Story 1, Hans, the supervisor of the procurement committee, is enjoining his staff to attend the meeting discussing the procurement problem in DJKN (line 2-4). From another source, ${ }^{12} \mathrm{We}$ have found that the problem is about the housing procurement for officials in Mamuju, West Sulawesi. Mamuju's project manager is questioning the criteria and procedures he should perform if he wants to execute the budget of official house provision via a buydirectly-from-developer mechanism. The meeting Hans ${ }^{13}$ asks Ari to attend is going to discuss further the mechanism.

\begin{tabular}{|c|c|c|}
\hline Henry & $\begin{array}{l}1 . \\
2 . \\
3 . \\
4 . \\
5 . \\
6 . \\
7 . \\
8 . \\
9 . \\
10 .\end{array}$ & $\begin{array}{l}\text { About our project in Mamuju, we do not know whether } \\
\text { the project manager could apply the buy-directly- } \\
\text { from-developer mechanism. } \\
\text { Although it is legal based on the regulation, } \\
\text { I have not found any institution carrying out the mechanism. } \\
\text { This is why your role here becomes important so that } \\
\text { Romadan could give us a valuable suggestion } \\
\text { about the procedure. } \\
\text { I hope you could help us by supporting } \\
\text { the implementation of a direct buying mechanism. }\end{array}$ \\
\hline Ari & $\begin{array}{l}11 . \\
12 . \\
13 .\end{array}$ & $\begin{array}{l}\text { I do agree with you about the legality of direct buying } \\
\text { the mechanism, but can you explain to us first about the } \\
\text { background of Mamuju's project? }\end{array}$ \\
\hline
\end{tabular}

\footnotetext{
${ }^{12}$ DJKN's Official Notice on House Procurement Issue, dated $18^{\text {th }}$ February 2019.

${ }^{13}$ To preserve the research ethics, all of the actor's names in this paper are pseudonyms. 


\begin{tabular}{|c|c|c|}
\hline & $\begin{array}{l}14 . \\
15 . \\
16 .\end{array}$ & $\begin{array}{l}\text { (Then, Henry invited Johan to explain about his experience in } \\
\text { building residences for officials in Jayapura, Papua. } \\
\text { He used the procurement of goods method). }\end{array}$ \\
\hline Johan & $\begin{array}{l}17 . \\
18 . \\
19 . \\
20 . \\
21 .\end{array}$ & $\begin{array}{l}\text { There were so many difficulties in executing the procurement } \\
\text { of goods for residency provision. } \\
\text { So, if the regulations have given us the authority for executing } \\
\text { the direct buying method, why are we not applying it for } \\
\text { Mamuju project? }\end{array}$ \\
\hline Ari & $\begin{array}{l}22 . \\
23 . \\
24 .\end{array}$ & $\begin{array}{l}\text { Before going too far, I think we need to clarify some issues } \\
\text { associated with the practical experiences in PUPR and LKPP's } \\
\text { opinion about the direct buying mechanism. }\end{array}$ \\
\hline
\end{tabular}

Figure 3: Terse Story 2 - The Reason of Mechanism Alteration

Source: Adapted from field notes, interview records on January 18th, 2019

Terse Story 2 tells you more about the meeting at DJKN head office. Ari, Munir, and Ron represent Romadan in the meeting, while Henry, chief coordinator for strategic projects, represents DJKN. Henry relies heavily on Romadan's resolution regarding the housing provision policy (lines 6-8). He figures out that there is no institution operating the procedure of buying mechanism, whereas, by regulation, it is allowed (line 4-5). The mechanism was not the institutional logic that prevailed in the field of residence provision, but the build method was. Henry persuades Ari and his team to give DJKN support for breaking the logic by executing the direct buying mechanism (lines 9-10). He lets Johan in to provide field experience insight in respect of house provision project in Papua (line 14-16). Johan unveils one strong reason to implement the buy-from-developer method in Terse Story 2 (line 19-20). Ari explains that the Mamuju case is a typical "go-or-no-go" case that cannot be solved without involving the other stakeholders in the decision-making process (lines 22-24).

\begin{tabular}{|c|c|c|}
\hline Hiro & $\begin{array}{l}1 . \\
2 . \\
3 . \\
4 . \\
5 . \\
6 . \\
7 . \\
8 . \\
9 . \\
10 .\end{array}$ & $\begin{array}{l}\text { There will be } 2 \text { projects in Mamuju for piloting the direct } \\
\text { buying mechanism. } \\
\text { One is under DJPB authority. } \\
\text { Another one is for DJKN. } \\
\text { Implementing the buy-directly-from-developer method is not } \\
\text { illicit at all as stated in Minister of Public Works and Housing } \\
\text { Regulation: } 22 / 2008 . \\
\text { Sadly, the regulation does not provide the criteria on how we } \\
\text { should execute a build or buy mechanism. } \\
\text { I personally face this problem for the first time. }\end{array}$ \\
\hline Andre & $\begin{array}{l}11 . \\
12 . \\
13 . \\
14 . \\
15 . \\
16 .\end{array}$ & $\begin{array}{l}\text { I think we have to get in touch with LKPP because } \\
\text { this case is related to LKPP authority. } \\
\text { As long as I concern, PUPR has no authority in regulating } \\
\text { the procurement procedure. } \\
\text { PUPR regulation is only pertinent to technical } \\
\text { details of the house. }\end{array}$ \\
\hline Hiro & 17. & If we want to do the direct buying things, the project \\
\hline
\end{tabular}




\begin{tabular}{|l|ll|}
\hline 18. & managers have to ensure that there is a ready stock house. \\
19. & It is important because the stock will guarantee the project \\
20. & the manager that he will get the house he needs. \\
21. & We should put it on the requirements list of developer criteria. \\
\hline
\end{tabular}

Figure 4: Terse Story 3 - Gathering Internal Proponents

Source: Adapted from field notes on January 29th, 2019

Terse Story 3 explains important findings at MOF Internal Auditor Office (Itjen). Hans and Ari visit MOF Internal Auditor Office to settle some issues raised from the DJKN meeting and gather auditors' support. They meet with Hiro (internal audit manager handling the MOF capital expenditure issue in DJKN), Andre (senior auditor), and his team. The discussion is about the direct buying scheme as a new solution for house provision in Mamuju (Terse Story 3). Itjen representatives indicate to accept Romadan proposition to implement the scheme not only in Mamuju but also in MOF as well (line 5-7). Hiro mentions that for the year 2019, MOF has two pilot projects for testing the scheme (lines 1-4). They are the housing project under the National Treasury Office (DJPB) and the Mamuju project of DJKN. Both institutions are appointed by the minister as the task forces ${ }^{14}$ to accomplish the pilots under a new scheme (line 1-2). After the meeting, Hiro ravels a background story of the selection of two pilot projects to Romadan representatives. ${ }^{15} \mathrm{He}$ presumes that MOF can be the first ministry to implement the scheme, but MOF needs to develop the criteria for determining which project should be executed via build mechanism or buy-directly-from-developer method.

There are so many local offices requesting the implementation of a direct buying method. ${ }^{16}$ MOF cannot grant any of their requests before resolving the criteria of make-or-buy decisions. ${ }^{17}$ To bolster the criteria development, MOF has selected two projects under DJPB and DJKN authority as the pilots. ${ }^{18}$ The most important aspect that has to be considered in developing the criteria is the availability of house inventory. Hiro insists that the housing developer must have sufficient house inventory to complete the project (line 17-18) so that it is expected to mitigate the risk of delay. In the meantime, Andre suggests Romadan communicate with LKPP regarding the procedure of direct buying scheme because it is still within LKPP functions (lines 11-12). Despite Romadan's attempts to shift the organizational logic by implementing a direct buying scheme, MOF and other institutions still have to follow the house technical specification rule as mandated in the PUPR regulations ${ }^{19}$ (line 15-16).

\begin{tabular}{|c|c|c|}
\hline Ardy & $\begin{array}{l}1 . \\
2 . \\
3 . \\
4 . \\
5 . \\
6 . \\
7 . \\
8 . \\
9 . \\
10 . \\
11 .\end{array}$ & $\begin{array}{l}\text { Essentially, our regulation has provided the institution } \\
\text { access to enhance the best practices in } \\
\text { all procurement areas. } \\
\text { I am not mentioning one type of procurement, not goods, } \\
\text { services, nor construction projects, but all of them. } \\
\text { I am saying that government procurement will eventually } \\
\text { follow the best practices. } \\
\text { We do not want to create rigid policies nor procedures. } \\
\text { So, in the case of MOF official house procurement, I hope that } \\
\text { MOF will be the first institution implementing the direct } \\
\text { buying mechanism and, further, the role model. }\end{array}$ \\
\hline Sean & 12. & In order to develop the direct buying criteria, you can adopt \\
\hline
\end{tabular}

\footnotetext{
${ }^{14}$ As stated on the MOF annual budget year 2019, only Mamuju Treasury Office and Mamuju Asset Management Office will implement the direct buying mechanism. The information has been confirmed by Hiro in post-meeting conversation on January 29, 2019.

${ }^{15}$ The Itjen and Romadan team had an extended conversation after the meeting on $29^{\text {th }}$ January 2019 . We didn't record the conversation but We memorized it, then We wrote the critical points in our field notes.

16 Ibid.

17 Ibid.

18 Ibid.

${ }^{19}$ Loc.cit. Number 4.
} 


\begin{tabular}{|c|c|c|}
\hline & $\begin{array}{l}13 . \\
14 . \\
15 . \\
16 . \\
17 . \\
18 . \\
19 . \\
20 . \\
21 . \\
22 . \\
23 .\end{array}$ & $\begin{array}{l}\text { the best practices in the field of house selection. } \\
\text { About the scope, you can choose whether you want to } \\
\text { implement the practices in full or partial adoption. } \\
\text { Full adoption means you can neglect } 3 \text { general procurement } \\
\text { processes from LKPP regulation by creating new procedures } \\
\text { of direct buying on house provision, from planning, selecting } \\
\text { the vendor, and executing the contract. } \\
\text { Partial adoption means among } 3 \text { general procurement } \\
\text { processes, you only have to execute one of them based on the } \\
\text { best practices, and for the remainders, you have to follow } \\
\text { LKPP rules. }\end{array}$ \\
\hline Ardy & $\begin{array}{l}24 . \\
25 . \\
26 . \\
27 . \\
28 .\end{array}$ & $\begin{array}{l}\text { In addition, MOF should also assign an internal regulation on } \\
\text { house provision. } \\
\text { The regulation should explain the decision criteria and } \\
\text { the procedures if MOF wants to perform buy-directly-from- } \\
\text { developer mechanism. }\end{array}$ \\
\hline
\end{tabular}

Figure 5: Terse Story 4 - Mechanism Shifting Approval

Source: Adapted from field notes on February 13th, 2019

Terse Story 4 describes the final story of the institutional logic change in the public housing field. Not long after the meeting with Itjen, Hans and Ari decide to visit the LKPP office at Kuningan, Central Jakarta (Terse Story 4). Their objectives are to discuss the MOF plan on establishing the internal regulation on official house provision and to gain information about LKPP experience in solving the housing problems. The chief of construction procurement policy, Ardy, and the chief of construction services policy, Sean, welcome Romadan representatives. Since Hans and Ari have expressed their interest in attempting direct buying implementation in MOF, Sean is delighted to support MOF and challenges them to make MOF a role model (line 9-11). He unveils that the procurement regulation is designed to adapt to the best practices (lines 1-5), in terms of the regulation does not arrange the details of procurement procedures. ${ }^{20}$ It only states the principles that have to be allowed in the 3 general procurement processes (lines 6-7; 12-15). Those processes are procurement planning, vendor selection, and contract execution (line 16-19).

Based on Terse Story 4, Sean of LKPP appends that the MOF representatives, Hans and Ari, have to look at the best practices in the field of residence provision (line 12-13). Afterward, he suggests them to adopt the principles of best practices for creating the basic criteria as well as procedures (line 12-13). Sean also tells the Romadan team the way they should develop the basic criteria of make-or-buy decisions for house procurement (line 14-15). He firmly states that if the decision is to buy residences directly from the developer, then MOF has to develop the buying procedures because they have not been ratified in any related regulations (lines 16-23). Furthermore, MOF has to enact an internal decree that has substance on the essential criteria of make-or-buy decision and direct buying procedures (lines 24-28). In sum, LKPP has the same understanding of MOF about the direct buying mechanism. LKPP also supports MOF in stipulating the internal decree on the multi-criteria decision-making and the direct buying procedures of house provision.

\section{The Reflection of Precedent Stories: The Key Roles of Key Actors}

What can be inferred from the precedent stories is that the dynamics of shifting organizational logic inside government institutions involve both internal and external stakeholders. In the case of MOF, there are several actors embroiled. The main actors are Hans and Ari of Romadan. Their roles are gathering every support they need from internal and external stakeholders to develop and implement the multi-criteria decision-making in the field of house provision. After the criteria are established in MOF regulation, direct buying is eligible to be implemented widely in MOF. However, the main actor roles are affected by supporting actor behavior. The supporting actors are Henry and Johan of DJKN. They have played their roles in influencing the Romadan team to start the initiation of a direct buying scheme in MOF, beginning with the Mamuju project. 


\section{The Second Objective, The Unfolding Stories: Constructing Criteria of House Provision}

After the LKPP meeting, Hans of Romadan asks us to help him develop the multi-criteria of make-or-buy decision. To fulfill his request, We need some insights from international best practices in the field of residency provision. Then we conduct a systematic review and use the review result to refine the storied narrative from precedent stories. The combined results of storied narrative and systematic review results are confirmed to Bob, a procurement expert of Romadan, who has more than eight years of field experience in the construction project. Bob accentuates two criteria recommendations to strengthen the make-or-buy decision model. Firstly, the unit must have no idle land asset based on the unit's statement of financial position and notes to financial statements. Secondly, the total cost of the housing project is sufficiently funded by the government, as stated in the unit's budget execution notice.

Two things are essential before you perform the buy-directly-from-developer mechanism! First, you have to make sure whether the unit that proposes the execution of the mechanism has an unused land asset in its working area. If the unit does not have any unused land, then you, as the asset manager of the ministry is obliged to locate an unused land in the other MOF units in the same working area. If there is no idle land asset in the area, then you can go on executing the mechanism. Second, the total fund of the house provision project has to be established in the unit budget. - Excerpt from an interview on August 23rd, 2019.

Then combined results of storied narrative and systematic review are incorporated with the meanings from the expert interview to generate the preliminary criteria decision-making of house provision (Table 3). We ran the six-steps AHP procedures to produce a consistent multi-criteria so that the MOF decision-makers can use them as a tool for generating consistent decisions. We presented the results of the procedures in Table 4-6 and Figure 6-9. What can be concluded from the AHP results are: first, to run the direct buying mechanism, the total scores of AHP calculation must be above 50. Otherwise, MOF strategic decision-makers shall select to implement the build procurement method. Second, We found exciting facts that amongst 7 criteria, the project decision-makers emphasize living environment, budget sufficiency, and land availability as the top 3 criteria with the highest scores. If the total scores among the top 3 combined, the results are $60,78 \%$. So, this means that there is a way to increase the possibility of a project to be executed with direct buying, that is, by maximizing the scores within the top 3 criteria. Meanwhile, we discovered the big 5 of sub-criteria of make-or-buy decisions that are pivotal in enhancing the buy-directly-from-developer decision for the official residency project. Those big five are land not used as paddy field, house price stated at fair value, safe from flood location, lush and serene ambiance, as well as developer experience.

Table 3: Preliminary Criteria of Make-or-Buy Decision of Official House Provision

\begin{tabular}{lll}
\hline No & Criteria & Sources \\
\hline 1 & Land Availability & Expert Interview; Romadan Internal Documents \\
\hline 2 & Budget Sufficiency & (Ashaf \& Hidayat, 2019; Prajanti, 2014; Li, Yu, \& Cheng, 2005); \\
& & Participatory Observation Results; Expert Interview \\
\hline 3 & Site Location & $\begin{array}{l}\text { (Deveci, Akyurt, \& Yavuz, 2018; Kauko, 2006; Roig-Tierno et } \\
\text { al., 2013) }\end{array}$ \\
\hline 4 & House Physical & (Chauhan, Shah, \& Rao, 2008; Hwang, Ko, \& Goan, 2007; Sun, \\
& & $\underline{\text { Pan, Wang, \& Zhang, 2013) }}$ \\
\hline 5 & Living Environment & (Cheng, Li, \& Yu, 2005; Johnson, 2001; Kuzman et al., 2013) \\
\hline 6 & Community Facilities & (Ball \& Srinivasan, 1994; Schniederjans et al., 1995; Yap, Ho, \& \\
\hline 7 & Developer Credibility & $\underline{\text { Ting, 2019) }}$ \\
\hline
\end{tabular}

Source: Adapted from Observation, Systematic Review, and Expert Interview Results

Based on the preliminary criteria, We conducted the first survey to 13 project representatives using a google form to test whether the criteria were matched with their experiences (Table 4). The criteria for selecting the project representatives are explained in the methodology section. The criteria proceeded into the next steps of AHP are the criteria that have 3points value of geometric mean and above (Saaty, 2004). The preliminary criteria are summarized in a 3-level hierarchy model (Figure 6

Table 4: Geometric Mean of Criteria and Sub-Criteria of Official House Provision

\begin{tabular}{lll}
\hline Codes & Criteria and Sub-Criteria & $\begin{array}{l}\text { Geometric } \\
\text { Mean }\end{array}$ \\
\hline X1 & Land Availability & $\mathbf{4 , 5 4}$ \\
\hline X11 & The unit has no idle land asset & 2,82 \\
\hline X12 & Land area complies with the Standards & 3,23 \\
\hline X13 & The land is not used as paddy field nor a swamp & 3,00 \\
\hline
\end{tabular}




\begin{tabular}{|c|c|c|}
\hline $\mathbf{X 2}$ & Budget Sufficiency & $\mathbf{4 , 5 7}$ \\
\hline $\mathrm{X} 21$ & House price is stated at fair market value & 4,78 \\
\hline $\mathrm{X} 22$ & House price is cheaper than total cost of self-constructed house & 4,37 \\
\hline $\mathrm{X} 23$ & House price is non-volatile & 4,04 \\
\hline $\mathrm{X} 24$ & House price covers purchase price, notarial fee, taxes, and excess of land & 4,57 \\
\hline $\mathbf{X 3}$ & Site Location & 4,78 \\
\hline $\mathrm{X} 31$ & Site location is relatively safe from flood and earthquake disaster & 4,65 \\
\hline X32 & Site location is nearby the work office & 4,68 \\
\hline X33 & Site location is closed to worship place & 4,47 \\
\hline $\mathbf{X 4}$ & House Physical & 4,78 \\
\hline $\mathrm{X} 41$ & $\begin{array}{l}\text { House area complies with minimum house area based on related } \\
\text { regulation }\end{array}$ & 4,54 \\
\hline $\mathrm{X} 42$ & $\begin{array}{l}\text { House complex has a water network channel connected to water supply } \\
\text { network system }\end{array}$ & 4,54 \\
\hline $\mathrm{X} 43$ & Material quality meets the minimum standard & 4,68 \\
\hline $\mathrm{X} 44$ & House facade is eye-catching & 3,98 \\
\hline X5 & Living Environment & 4,68 \\
\hline X51 & The living environment is safe from social conflict & 4,78 \\
\hline $\mathrm{X} 52$ & House complex is placed in the one-gate system or cluster system & 4,54 \\
\hline $\mathrm{X} 53$ & Quietness level is relatively high & 4,68 \\
\hline $\mathrm{X} 54$ & House complex has paved road & 4,68 \\
\hline X6 & Community Facility & 4,35 \\
\hline X61 & House complex has green public space & 4,16 \\
\hline X62 & House complex has public playing ground & 3,89 \\
\hline $\mathbf{X 7}$ & Developer Credibility & 4,68 \\
\hline $\mathrm{X} 71$ & The developer has ready-stock houses & 4,54 \\
\hline $\mathrm{X} 72$ & The developer has a healthy financial performance & 5,00 \\
\hline $\mathrm{X} 73$ & The developer has three completed project experiences & 4,89 \\
\hline $\mathrm{X} 74$ & The developer is a corporate legal entity & 4,65 \\
\hline
\end{tabular}

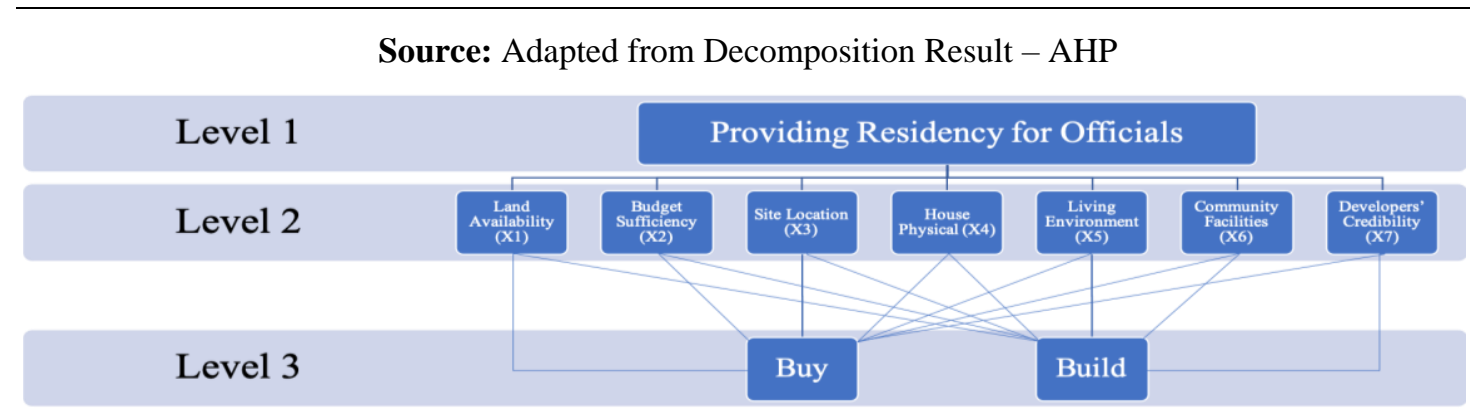

Figure 6: Hierarchy of Official House Provision

Source: Adapted from Observation, Systematic Review, and Expert Interview Results

To weigh which criterion is more important than another, we underwent the second survey to 10 strategic decisionmakers. The criteria and sub-criteria from the preliminary survey were being tested by applying AHP-style questionnaires with the 9-points scale measurements adopted from Ball and Srinivasan (1994). The survey results were used to compose the PCM for the main criteria of the decision-making model for residence provision (Figure 7). Using the PCM data, we exercised the priority vector normalization and consistency test procedures to calculate the consistency ratio of the main criteria (Figure 8). For each main criteria, the consistency ratio must be above 0,10 to be accepted as the final main criteria (Saaty, 1982). 
Figure 7: Average PCM Main Criteria of Official House Provision

\begin{tabular}{cccccccc}
\hline CRITERIA & $\mathbf{X 1}$ & $\mathbf{X 2}$ & $\mathbf{X 3}$ & $\mathbf{X 4}$ & $\mathbf{X 5}$ & $\mathbf{X 6}$ & $\mathbf{X 7}$ \\
\hline $\mathbf{X 1}$ & 1,00 & 1,04 & 1,36 & 3,60 & 0,85 & 1,82 & 1,70 \\
\hline $\mathbf{X 2}$ & 0,96 & 1,00 & 1,45 & 3,41 & 1,34 & 2,57 & 1,84 \\
\hline $\mathbf{X 3}$ & 0,73 & 0,69 & 1,00 & 3,47 & 0,53 & 2,92 & 1,03 \\
\hline $\mathbf{X 4}$ & 0,28 & 0,29 & 0,29 & 1,00 & 0,21 & 0,94 & 0,38 \\
\hline $\mathbf{X 5}$ & 1,17 & 0,75 & 1,90 & 4,87 & 1,00 & 4,27 & 1,40 \\
\hline $\mathbf{X 6}$ & 0,55 & 0,39 & 0,34 & 1,06 & 0,23 & 1,00 & 0,39 \\
\hline $\mathbf{X 7}$ & 0,59 & 0,54 & 0,97 & 2,64 & 0,71 & 2,58 & 1,00 \\
\hline Total & 5,28 & 4,70 & 7,32 & 20,05 & 4,87 & 16,10 & 7,73 \\
\hline
\end{tabular}

Source: Adapted from AHP Results

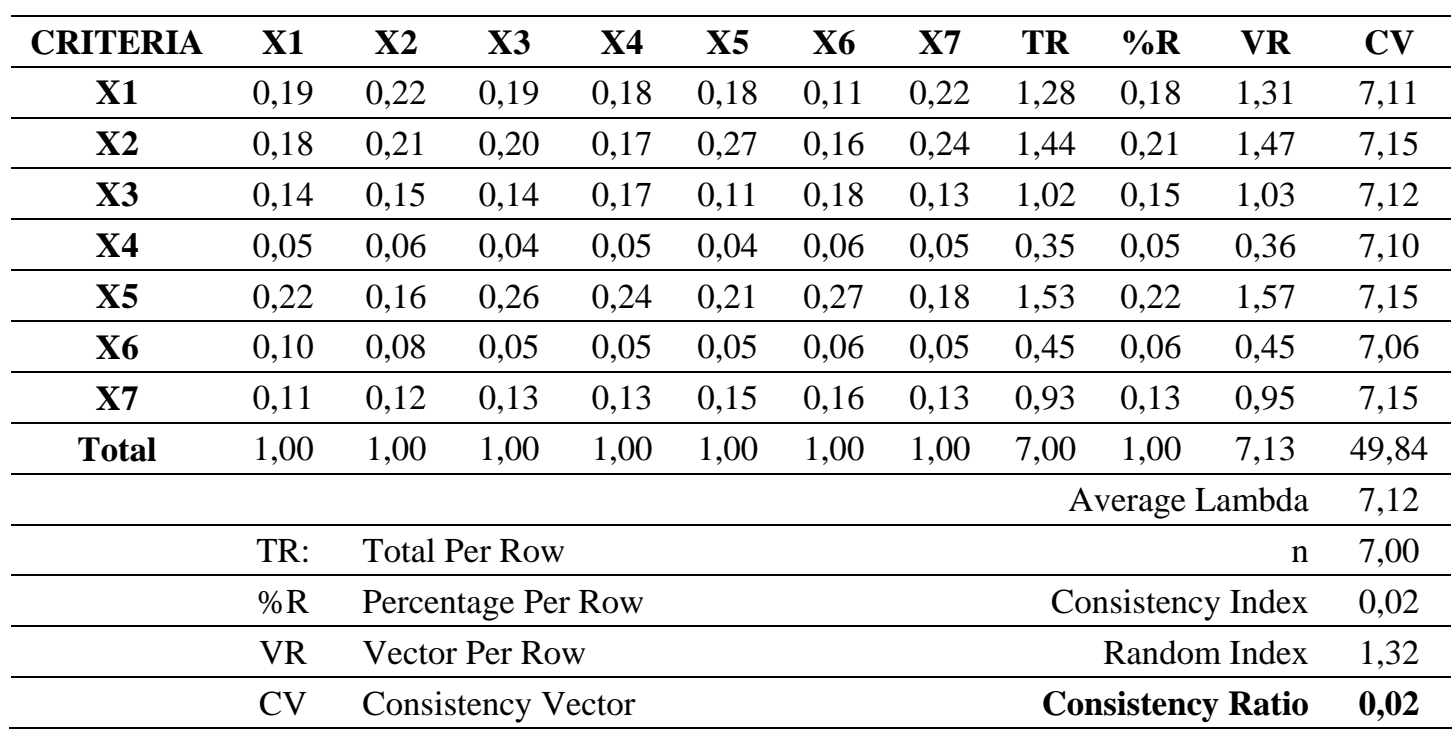

Figure 8: Consistency Ratio of Main Criteria of Official House Provision

Source: Adapted from AHP Results

We used the steps of calculating the consistency ratio of the main criteria to compose the consistency ratio for subcriteria. For each sub-criteria, the consistency ratio has to be above 0,10 to be approved as the final sub-criteria (Saaty, 1982). The conclusion of the PCM consistency test for sub-criteria 1 to 7 is that all seven sub-criteria are consistent because their consistency ratio is beyond 0,10 each. It means that the model can be implemented widely to provide the best decision (Ball \& Srinivasan, 1994) in the field of public housing provision in Indonesia. If the consistency is poor or below $10 \%$, supplementary information is needed to trace where the inconsistent information is derived from (Schniederjans, Hoffman, \& Sirmans, 1995). The researchers should make sure that the expert as a research informant who provides that kind of information understands how to answer the AHP questionnaire (Saaty, 2004). The expert should build a prioritization of their preference before answering the questionnaire (Lai et al., 2002). The process of revising the answer should be conducted iteratively until the informant provides a consistent answer (Mani, Agrawal, \& Sharma, 2014). From there, the consistent model of multi-criteria decision-making is constructed (Obeidat, Qasim, \& Khanfar, 2018).

Rectifying the consistency ratio does not mean gaining the obvious answer to the issue being researched (Ball \& Srinivasan, 1994). We agree, to some extent, with Ball and Srinivasan's (1994) argument saying that "the improving consistency ratio only indicates that the ratio is getting closer to being logically connected than to being randomly picked out." Based on the results of the consistency test for the main criteria and sub-criteria, the final weights of the multi-criteria decision-making model for residence provision are shown in Table 5 and summarized into the hierarchy in Figure 9.

Table 5: Final Weights of Multi-Criteria Model of Official House Provision

\begin{tabular}{llc}
\hline Codes & Criteria and Sub-Criteria & Weights \\
\hline & & \\
\hline X1 & Land Availability & $18,34 \%$ \\
\hline
\end{tabular}




\begin{tabular}{|c|c|c|}
\hline $\mathrm{X} 11$ & The unit has no idle land asset & $5,27 \%$ \\
\hline $\mathrm{X} 12$ & Land area complies with the Standards & $4,75 \%$ \\
\hline $\mathrm{X} 13$ & The land is not used as paddy field nor a swamp & $8,33 \%$ \\
\hline $\mathbf{X 2}$ & Budget Sufficiency & $20,52 \%$ \\
\hline $\mathrm{X} 21$ & House price is stated at fair market value & $9,84 \%$ \\
\hline $\mathrm{X} 22$ & House price is lower than the total cost of the self-constructed house & $1,84 \%$ \\
\hline $\mathrm{X} 23$ & House price is non-volatile & $4,55 \%$ \\
\hline $\mathrm{X} 24$ & House price covers purchase price, notarial fee, taxes, and excess of land & $4,29 \%$ \\
\hline $\mathbf{X 3}$ & Site Location & $14,53 \%$ \\
\hline $\mathrm{X} 31$ & Site location is relatively safe from flood and earthquake disaster & $6,34 \%$ \\
\hline $\mathrm{X} 32$ & Site location is nearby the work office & $5,20 \%$ \\
\hline $\mathrm{X} 33$ & Site location is closed to worship place & $2,98 \%$ \\
\hline $\mathbf{X 4}$ & House Physical & $5,06 \%$ \\
\hline $\mathrm{X} 41$ & House area complies with minimum house area based on related regulation & $1,76 \%$ \\
\hline $\mathrm{X} 42$ & $\begin{array}{l}\text { House complex has a water network channel connected to water supply network } \\
\text { system }\end{array}$ & $1,02 \%$ \\
\hline $\mathrm{X} 43$ & Material quality meets the minimum standard & $1,68 \%$ \\
\hline $\mathrm{X} 44$ & House facade is eye-catching & $0,60 \%$ \\
\hline $\mathbf{X 5}$ & Living Environment & $21,92 \%$ \\
\hline $\mathrm{X} 51$ & The living environment is safe from social conflict & $3,50 \%$ \\
\hline $\mathrm{X} 52$ & House complex is placed in the one-gate system or cluster system & $1,30 \%$ \\
\hline $\mathrm{X} 53$ & Quietness level is relatively high & $12,97 \%$ \\
\hline $\mathrm{X} 54$ & House complex has paved road & $4,14 \%$ \\
\hline X6 & Community Facility & $6,38 \%$ \\
\hline X61 & House complex has green public space & $2,60 \%$ \\
\hline X62 & House complex has public playing ground & $3,78 \%$ \\
\hline $\mathbf{X 7}$ & Developer Credibility & $13,25 \%$ \\
\hline $\mathrm{X} 71$ & The developer has ready-stock houses & $1,73 \%$ \\
\hline $\mathrm{X} 72$ & The developer has a healthy financial performance & $3,94 \%$ \\
\hline $\mathrm{X} 73$ & The developer has three completed project experiences & $4,79 \%$ \\
\hline $\mathrm{X} 74$ & The developer is a corporate legal entity & $2,79 \%$ \\
\hline
\end{tabular}

Source: Adapted from AHP Results

A preview of the final factor weights displayed in Table 5 was synthesized from the PCM priority and resulting proportions of decision-making determinants like land availability, budget sufficiency, site location, house physical quality, living environment, community facility, and developer credibility. Generally, the results propose that the project managers in the public sector field consider the living environment as the first determinant for implementing the buying mechanism. Coming up into the second position is budget sufficiency. The third place is occupied by land availability and house location as the fourth rank. Developer credibility takes the fifth position. Community facility and house quality are placed in the last two positions.

Placing the house quality as the less important determinant is opposing the findings of Ismail and Shari's (2019) research as well as $\underline{\text { Ho et al. (2005) }}$ study. Their researches (Ho et al., 2005; Ismail \& Shaari, 2019) place house quality as the major reason why project managers should execute the buying mechanism. This research differs from previous ones because the government of Indonesia has stipulated a specific regulation on public sector housing. The regulation governs the technical aspects of house physical quality, meaning that every developer contracted by the public project managers in Indonesia should follow the technical requirements described in the regulation (Qadri, 2019). Henry of DJKN explained more about the reason for positioning the house quality as the less attractive trigger on implementing the buying strategy: "the quality of the public dwelling has general standards. It is regulated by the Ministry of Public Works' decree on the technical specification of public housing. When buying the house, you have to refer to the 
regulation in order to make sure that the quality and appropriateness of the residence comply with it. The house should not be too bad nor too luxurious." - interview script on November 11, 2019.

The indicators defining the house physical quality comprise of several sub-criteria refined from previous literature (Fierro, Fullerton, \& Donjuan-Callejo, 2009; Ho et al., 2005; Ismail \& Shaari, 2019; Sun et al., 2013) including interview results and synthesized from the AHP procedures of analysis (Ball \& Srinivasan, 1994; Saaty, 2004). Those indicators are (1) house area complying with the minimum house area standard based on the related regulation; (2) house connected to local water supply system; (3) material quality adhering to the minimum standard; and (4) eye-catching facade. These findings are aligning with the necessity of the stakeholders in the Indonesia public housing field. Grum and Kobal-Grum (2015) stressed similar findings regarding the criteria to define physical factors of house quality. They argued that "determinant analysis generates several decisive factors of buying a property... one of which is pointing to the criteria on house physical quality. They are the size of the property and material quality of dwelling" (Grum \& Kobal-Grum, 2015).

Our findings suggest that the living environment is the most attractive trigger in affecting the buying decision of public houses in Indonesia. There is a strong relationship between the living environment and house consumption by home buyers, especially the old ones (Wu, 2010). The proposition is supported by one of Ismail and Shari (2019) findings stating that: "the key attraction trigger for the baby boomers generation to execute the buying strategy for housing is neighborhood [living environment]." Baby boomers generation are people who were born between 1945-1954 (Leach, Phillipson, Biggs, \& Money, 2008; Roberts, 2012). Our findings buttressed the findings by Wu (2010) and also Ismail and Shari (2019) as emphasized by a "baby boomers" project manager at MOF of Indonesia, from the interview on $9^{\text {th }}$ November 2019, stating that "the living environment is the key factor to execute the buying mechanism on public housing project ... and a cluster housing with one gate security is more suitable for public residences. " His argument is strong evidence to support the relationship between the living environment and the implementation of buy strategy for public residency, as Bender et al. (2000) highlighted that a high level of environmental quality supplies more allure to home buyers.

We found that the most pivotal determinant constructing the criteria of the living environment is high quietness level, followed by a paved residential road, safe from social conflict, and one-gate system neighborhood. The level of quietness is the top-ranked determinant of the living environment because most project managers we have surveyed argued that a high level of quietness is important for the employees to fresh up their minds after spending most of their time at the office. This argument is aligned with Bender et al. (2000) study eliciting the fact that home buyers are leaving their apartment to buy a house that has a high level of quietness. "People choosing to buy a residence are normally going away from a flat where the loud sound sources are notable. If they opt to buy a residence, which signifies a large financial commitment, they desire to be in a quiet neighborhood" (Bender et al., 2000).

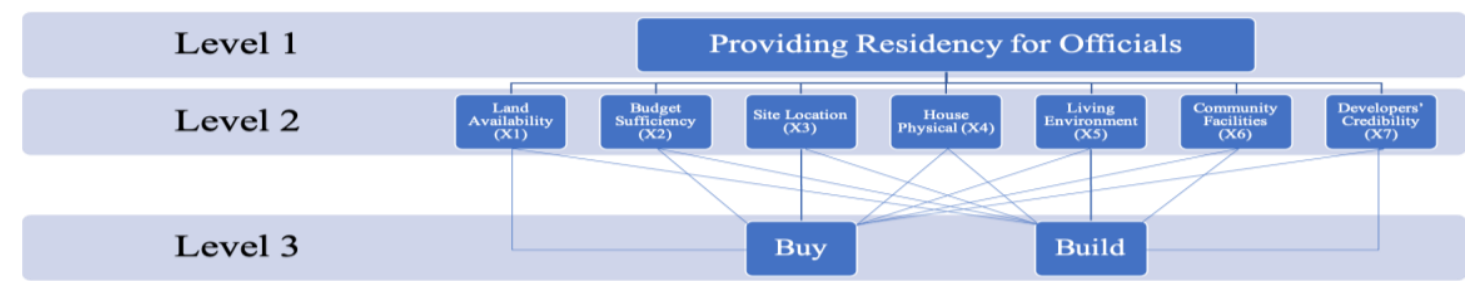

Figure 9: Final Model of Make-or-Buy Decision of Official House Provision

\section{Source: Adapted from AHP Result}

The final model of multi-criteria decision-making for public dwelling presented in Figure 9 proposes seven determinants to execute the buying mechanism for providing public housing. They are (1) land availability, (2) budget sufficiency, (3) house location, (4) house physical quality, (5) living environment, (6) community facility, and (7) developer credibility. The main objective of the final model is to define logically 'which option to carry out' when project managers have a number of public dwelling projects to execute (Level 1 of Figure 9). In making the decision to run the buy a residence mechanism, project managers should perform multiple sets of procedures (Level 2 of Figure 9) by evaluating the makeor-buy criteria until arriving at the final decision (Level 3 of Figure 9). In order to execute the buying decision, the cumulative scores should be above 50\% (Ball \& Srinivasan, 1994). Otherwise, the public sector project managers have to carry out the make a dwelling procedure (Chauhan et al., 2008). However, project managers should pay attention to developer opportunistic behavior (Serrano, Ramírez, \& Gascó, 2018). Using our final model for decision-making in public housing provision can reduce the risk of opportunism by providing a fair judgment on every vendor proposal. Thus, our research is consistent with the transaction cost economics theory, which evokes a proposition that the make-orbuy decision has a strong relationship with the degree of opportunism surfaced (Dibbern, Goles, Hirschheim, \& Jayatilaka, 2004). Therefore, our research basically is strong evidence that the transaction cost economics theory does exist. 


\section{The Third Objective, The Upcoming Stories: Predicting the Future of Public Residency Provision}

Based on the precedent stories, the government limits the mechanism for procuring state houses only in four ways, namely: build, exchange, grant, or buy-directly-from developer. ${ }^{21}$ As explained earlier in this paper, the provision of official residence is carried out mostly through build mechanism. This study proposes the government with a framework to decide whether a project shall be executed with a build mechanism or direct buying method. Even so, the four methods have long been abandoned by most developed countries as they utilize the concept of public services partnership in managing housing projects (Morrison, 2016). The partnership framework is a breath of fresh air adopted by England (Mullins \& Moore, 2018) and several commonwealth countries, such as Northern Ireland (Muir \& Mullins, 2015), Scotland (Gibb, 2003), and Australia (Nygaard, Berry, \& Gibb, 2008). The framework overlies in the form of a hybrid financing scheme: the provision of public housing is handed over to non-profit organization in the real estate sector (Blessing, 2012), then the total costs of provision are divided proportionally between the government and the nonprofit organization (Moore, 2018).

The non-profit organization then conducts the procurement mechanism by carrying out two main principles: considering value-for-money in price negotiations and implementing a design-and-build contract (Goodchild \& Chamberlain, 1999). The partnership model has become the best practices that are adopted globally (Cabré \& Andrés, 2018; Muir \& Mullins, 2015; Mullins \& Moore, 2018). However, MOF project managers have not captured the issue. They still contend that the implementation of a buy-directly-from-developer mechanism should immediately be performed as the alternative solution to improve the efficiency in the period of the official residency provision as well as boost the budget realization. Maintaining the effectiveness of housing projects is also crucial in managers' opinions. Only by making sure that the project's outputs have met the minimum public residence standards can the public project managers implement the buying mechanism. In the future: "the official house management shall follow principles of the international best practices in the public services partnership." - stated by informant Zack, Chief of MOF Procurement Centre. ${ }^{22}$

\section{CONCLUSION}

This research aims to elucidate the dynamics of change in the organizational logic shifting of public dwelling provision praxis in Indonesia, and compose multi-criteria decision-making for public residence project using the versatile approach of the analytic hierarchy process as well as explicate the future of public residency outsourcing. The results unveil interesting findings that several actors play their part in shifting the institutional logic of public housing provision in Indonesia. The most influential actors are coming from the MOF because the MOF has been appointed by the National Procurement Authority as the pilot ministry for implementing the new logic of the buy-directly-from-developer mechanism. Then the MOF is urged by the authority to start the implementation by composing the multi-criteria decision-making model of the make-or-buy decision on public residence provision.

We helped the MOF through this research to compose the criteria. We found that the most important determinant among MOF project managers in executing the buying mechanism is the living environment, followed by budget sufficiency, land availability, house location, vendor credibility, community facility, and house quality. The government can run the buy-directly-from-customer method if the total scores of AHP calculation are above 50\%. Otherwise, the government shall opt to exercise the build mechanism. Our study also reveals that there are five criteria for the buy-or-build decision that play major roles in influencing buying decisions for the official residency project. Those five are land not used as paddy field, house price stated at fair value, safe from flood location, lush and serene ambiance, as well as developer experience. Previous studies in the area of official residency provisions are infrequent. However, the future of public housing provision is bright. In the future, public sector project managers should think creatively to fund their projects because the government budget will be limited. To tackle the upcoming issue, implementing the public-private partnership scheme may be the best alternative solution.

\section{LIMITATION AND STUDY FORWARD}

This study might be the only one of its kind; notwithstanding, the paper provides several implications to both theory and praxis. Firstly, the paper contributes to the public sector accounting field, especially in the area of asset management and public housing procurement. The paper gives a strong framework for the field to make use of the model of Indonesia's public housing provision. Secondly, this study refines the transaction cost economics theory by providing evidence supporting the postulate. Thirdly, this research determines a framework for the government of multi-attribute criteria of the make-or-buy decision in official housing provision. The government can adopt our research framework for exploiting the option. The framework was abstracted from grounded data of excessive interviews. However, the efforts to contemplate the meanings of those data were relentless and time-consuming. So this research has not covered the issues related to the framework's implementation. Thus, further research should carry on the mission to scrutinize the implementation effect after the framework is being implemented widely. Last but not least, we evoke you with an idiom: 'buy thou house or continue thy dream then thou hast only thyself to blame.'

\footnotetext{
${ }^{21}$ Loc.cit. Number 4.

${ }^{22}$ Confirmation via WhatsApp message on October 10, 2019.
} 


\section{ACKNOWLEDGMENT}

We would like to express our utmost gratitude to The Research Centre of Polytechnic of State Finance STAN, Indonesia, for the financial supports. Also, we would like to thank Ferry Irawan, Suparna Wijaya, Deni Herdiana, Zeff Arfiansyah, and two anonymous reviewers for comments that essentially rectified this article. The usual disclaimer prevails.

\section{AUTHORS CONTRIBUTION}

The co-author has contributed to reviewing the validity of the formula and results derived from the execution of the formula. Also, the co-author has provided the proofreading performative towards this paper.

\section{REFERENCES}

1. Ahsan, K., \& Gunawan, I. (2010). Analysis of cost and schedule performance of international development projects. International Journal of Project Management, $28(1), \quad 68-78$. https://doi.org/10.1016/j.ijproman.2009.03.005

2. Arnaboldi, M., Lapsley, I., \& Steccolini, I. (2015). Performance Management in the Public Sector: The Ultimate Challenge. Financial Accountability \& Management, 31(1), 1-22. https://doi.org/10.1111/faam.12049

3. Ashaf, D. H., \& Hidayat, S. W. (2019). Decision Support System Determines The Purchase of House Right Using Analytical Hierarchy Process (AHP) and Borda Methods. International Journal of ASRO, 10(1), 1-9.

4. Astadi, N. G., Sutarja, I. N., \& Nadiasa, M. (2015). Analisis Sistem Pengadaan Proyek Konstruksi Terhadap Penyerapan Anggaran Pemerintah Kabupaten Badung. Jurnal Spektran, 3(1), 82-89. https://doi.org/10.24843/SPEKTRAN.2015.v03.i01.p010

5. Ball, J., \& Srinivasan, V. C. (1994). Using the Analytic Hierarchy Process in house selection. The Journal of Real Estate Finance and Economics, 9(1), 69-85. https://doi.org/10.1007/BF01153589

6. Bender, A., Din, A., Hoesli, M., \& Brocher, S. (2000). Environmental preferences of homeowners. Journal of Property Investment \& Finance, 18(4), 445-455. https://doi.org/10.1108/14635780010345391

7. Blessing, A. (2012). Magical or Monstrous? Hybridity in Social Housing Governance. Housing Studies, 27(2), 189-207. https://doi.org/10.1080/02673037.2012.649469

8. Bockman, J. (2018). Removing the public from public housing: Public-private redevelopment of the Ellen Wilson Dwellings in Washington, DC. Journal of Urban Affairs, 2166(May), 1-21. https://doi.org/10.1080/07352166.2018.1457406

9. Boje, D. M. (1991). Consulting and Change in the Storytelling Organisation. Journal of Organizational Change Management, 4(3), 7-17. https://doi.org/10.1108/EUM0000000001193

10. Boje, D. M. (1995). Stories of the Storytelling Organization: A Postmodern Analysis of Disney As "Tamara Land". Academy of Management Journal, 38(4), 997-1035. https://doi.org/10.5465/256618

11. Boje, D. M. (2019). Organizational Research Storytelling in Action. In Taylor \& Francis (First Edit). New York: Routledge. https://doi.org/10.4324/9781315205854

12. Boje, D. M., Rosile, G. A., Durant, R. A., \& Luhman, J. T. (2004). Enron Spectacles: A Critical Dramaturgical Analysis. Organization Studies, 25(5), 751-774. https://doi.org/10.1177/0170840604042413

13. Cabré, E., \& Andrés, A. (2018). La Borda: a case study on the implementation of cooperative housing in Catalonia. International Journal of Housing Policy, 18(3), 412-432. https://doi.org/10.1080/19491247.2017.1331591

14. Chai, C. S., \& Yusof, A. M. (2015). SEM Approach: Reclassifying Housing Delay in Malaysian Housing Industry. Journal of Economics, Business and Management, 3(3), 364-369. https://doi.org/10.7763/JOEBM.2015.V3.211

15. Chauhan, K. A., Shah, N. C., \& Rao, V. R. (2008). The Analytic Hierarchy Process as a Decision-Support System in the Housing Sector: A Case Study. World Applied Sciences Journal, 3(4), 609-613.

16. Cheng, E. W. 1., Li, H., \& Yu, L. (2005). The analytic network process (ANP) approach to location selection: a shopping mall illustration. Construction Innovation, 5(2), 83-97. https://doi.org/10.1108/14714170510815195

17. Czischke, D. (2009). Managing Social Rental Housing in the EU: A Comparative Study. European Journal of Housing Policy, 9(2), 121-151. https://doi.org/10.1080/14616710902920223

18. Czischke, D., \& van Bortel, G. (2018). An exploration of concepts and polices on 'affordable housing' in England, Italy, Poland and The Netherlands. Journal of Housing and the Built Environment. https://doi.org/10.1007/s10901-018-9598-1

19. Deveci, M., Akyurt, I. Z., \& Yavuz, S. (2018). A GIS-based interval type-2 fuzzy set for public bread factory site selection. Journal of Enterprise Information Management, 31(6), 820-847. https://doi.org/10.1108/JEIM$\underline{02-2018-0029}$

20. Dibbern, J., Goles, T., Hirschheim, R., \& Jayatilaka, B. (2004). Information Systems Outsourcing: A Survey and Analysis of the Literature. Data Base for Advances in Information Systems, 35(4), 6-102. https://doi.org/10.1145/1035233.1035236

21. Duarte, A., Souza, R., Macau, F., \& Souza, L. (2017). Supply Strategy: A Quasi-Experiment on the Number And Location of Suppliers. Brazilian Business Review, 14(5), 528-543. 
https://doi.org/10.15728/bbr.2017.14.5.5

22. Durdyev, S., Omarov, M., \& Ismail, S. (2017). Causes of delay in residential construction projects in Cambodia. Cogent Engineering, 4(1), 1-12. https://doi.org/10.1080/23311916.2017.1291117

23. Erbıyık, H., Özcan, S., \& Karaboğa, K. (2012). Retail Store Location Selection Problem with Multiple Analytical Hierarchy Process of Decision Making an Application in Turkey. Procedia - Social and Behavioral Sciences, 58, 1405-1414. https://doi.org/10.1016/j.sbspro.2012.09.1125

24. Field, B. (1987). Public housing in Singapore. Land Use Policy, 4(2), 147-156. https://doi.org/10.1016/0264$\underline{8377(87) 90048-2}$

25. Fierro, K. P., Fullerton, T. M., \& Donjuan-Callejo, K. E. (2009). Housing Attribute Preferences in a Northern Mexico Metropolitan Economy. Atlantic Economic Journal, 37(2), 159-172. https://doi.org/10.1007/s11293009-9174-X

26. Gardezi, S. S. S., Manarvi, I. A., \& Gardezi, S. J. S. (2014). Time Extension Factors in Construction Industry of Pakistan. Procedia Engineering, 77, 196-204. https://doi.org/10.1016/j.proeng.2014.07.022

27. Gerbl, M., McIvor, R., \& Humphreys, P. (2016). Making the business process outsourcing decision: why distance matters. International Journal of Operations and Production Management, 36(9), 1037-1064. https://doi.org/10.1108/IJOPM-04-2014-0192

28. Gibb, K. (2003). Transferring Glasgow's council housing: Financial, urban and housing policy implications. European Journal of Housing Policy, 3(1), 89-114. https://doi.org/10.1080/1461671032000071146

29. Goodchild, B., \& Chamberlain, O. (1999). Building procurement in social housing in Britain: A review of the main issues. Housing Studies, 14(6), 861-880. https://doi.org/10.1080/02673039982588

30. Grum, B. (2017). Impact of facilities maintenance on user satisfaction. Facilities, 35(7/8), 405-421. https://doi.org/10.1108/F-03-2016-0034

31. Grum, B., \& Kobal Grum, D. (2015). A model of real estate and psychological factors in decision-making to buy real estate. Urbani Izziv, 26(1), 82-91. https://doi.org/10.5379/urbani-izziv-en-2015-26-01-002

32. Gunasekaran, A., Subramanian, N., \& Rahman, S. (2015). Supply chain resilience: role of complexities and strategies. International Journal of Production Research, 53(22), 6809-6819. https://doi.org/10.1080/00207543.2015.1093667

33. Handley, S. M., \& Benton, W. C. (2012). The influence of exchange hazards and power on opportunism in outsourcing relationships. Journal of Operations Management, 30(1-2), 55-68. https://doi.org/10.1016/j.jom.2011.06.001

34. Heracleous, L., \& Barrett, M. (2001). Organizational change as discourse: Communicative actions and deep structures in the context of information technology implementation. Academy of Management Journal, 44(4), 755-778. https://doi.org/10.2307/3069414

35. Ho, D., Newell, G., \& Walker, A. (2005). The importance of property-specific attributes in assessing CBD office building quality. Journal of Property Investment \& Finance, 23(5), 424-444. https://doi.org/10.1108/14635780510616025

36. Humphreys, P. ., Lo, V. H. ., \& McIvor, R. . (2000). A decision support framework for strategic purchasing. Journal of Materials Processing Technology, 107(1-3), 353-362. https://doi.org/10.1016/S09240136(00)00729-9

37. Hung, W.-H., Lin, C.-P., Tai, Y.-M., Ho, C.-F., \& Jou, J.-J. (2014). Exploring the impact of Web-based eprocurement on performance: organisational, interorganisational, and systems perspectives. International Journal of Logistics Research and Applications, 17(3), 200-215. https://doi.org/10.1080/13675567.2013.837431

38. Hwang, B. G., Zhao, X., \& Ng, S. Y. (2013). Identifying the critical factors affecting schedule performance of public housing projects. Habitat International, 38, 214-221. https://doi.org/10.1016/j.habitatint.2012.06.008

39. Hwang, H. S., Ko, W.-H., \& Goan, M.-J. (2007). Web-based multi-attribute analysis model for make-or-buy decisions. Mathematical and Computer Modelling, 46(7-8), 1081-1090. https://doi.org/10.1016/j.mcm.2007.03.021

40. Ismail, H., \& Shaari, S. M. (2019). Housing decision: the choice between location, house and neighbourhood among malaysian generations. MATEC Web of Conferences, 266, 01026. https://doi.org/10.1051/matecconf/201926601026

41. Johnson, M. R. (2001). Decision support for family relocation decisions under the Section 8 housing assistance program using geographic information systems and the analytical hierarchy process. Journal of Housing Research, 12(2), 227-308.

42. Kamayanti, A. (2016). Metodologi Penelitian Kualitatif Akuntansi Pengantar Religiositas Keilmuan (Ke Dua; A. D. Mulawarman, ed.). Jakarta: Yayasan Rumah Peneleh.

43. Kaming, P. F., Olomolaiye, P. O., Holt, G. D., \& Harris, F. C. (1997). Factors influencing construction time and cost overruns on high-rise projects in Indonesia. Construction Management and Economics, 15(1), 83-94. https://doi.org/10.1080/014461997373132

44. Kauko, T. (2006). What makes a location attractive for the housing consumer? Preliminary findings from 
metropolitan Helsinki and Randstad Holland using the analytical hierarchy process. Journal of Housing and the Built Environment, 21(2), 159-176. https://doi.org/10.1007/s10901-006-9040-y

45. Kauko, T. (2007). An analysis of housing location attributes in the inner city of Budapest, Hungary, using expert judgements. International Journal of Strategic Property Management, 11(4), 209-225. https://doi.org/10.3846/1648715X.2007.9637570

46. Kimhur, B. (2020). How to Apply the Capability Approach to Housing Policy? Concepts, Theories and Challenges. Housing, Theory and Society, 37(3), 257-277. https://doi.org/10.1080/14036096.2019.1706630

47. Kuo, R. J., Chi, S. C., \& Kao, S. S. (2002). A decision support system for selecting convenience store location through integration of fuzzy AHP and artificial neural network. Computers in Industry, 47(2), 199-214. https://doi.org/10.1016/S0166-3615(01)00147-6

48. Kuzman, M. K., Grošelj, P., Ayrilmis, N., \& Zbašnik-Senegačnik, M. (2013). Comparison of passive house construction types using analytic hierarchy process. Energy and Buildings, 64, 258-263. https://doi.org/10.1016/j.enbuild.2013.05.020

49. Lai, V. S., Wong, B. K., \& Cheung, W. (2002). Group decision making in a multiple criteria environment: A case using the AHP in software selection. European Journal of Operational Research, 137(1), 134-144. https://doi.org/10.1016/S0377-2217(01)00084-4

50. Lang, R., \& Novy, A. (2014). Cooperative Housing and Social Cohesion: The Role of Linking Social Capital. European Planning Studies, 22(8), 1744-1764. https://doi.org/10.1080/09654313.2013.800025

51. Leach, R., Phillipson, C., Biggs, S., \& Money, A. (2008). Sociological perspectives on the baby boomers: An exploration of social change. Quality in Ageing and Older Adults, 9(4), 19-26. https://doi.org/10.1108/14717794200800024

52. Li, H., Yu, L., \& Cheng, E. W. L. (2005). A GIS-based site selection system for real estate projects. Construction Innovation, 5(4), 231-241. https://doi.org/10.1108/14714170510815276

53. Li, L. H. (2008). The physical environment and a "sense of neighborhood" in residential communities in Hong Kong. Property Management, 26(1), 7-24. https://doi.org/10.1108/02637470810848868

54. Mani, V., Agrawal, R., \& Sharma, V. (2014). Supplier selection using social sustainability: AHP based approach in India. International Strategic Management Review. https://doi.org/10.1016/j.ism.2014.10.003

55. Mantel, S. P., Tatikonda, M. V, \& Liao, Y. (2006). A behavioral study of supply manager decision-making: Factors influencing make versus buy evaluation. Journal of Operations Management, 24(6), 822-838. https://doi.org/10.1016/j.jom.2005.09.007

56. Marshall, D., Ambrose, E., McIvor, R., \& Lamming, R. (2015). Self-interest or the greater good how political and rational dynamics influence the outsourcing process. International Journal of Operations and Production Management, 35(4), 547-576. https://doi.org/10.1108/IJOPM-03-2013-0124

57. McCord, J., McCord, M., Davis, P. T., Haran, M., \& Rodgers, W. J. (2015). Understanding delays in housing construction: evidence from Northern Ireland. Journal of Financial Management of Property and Construction, 20(3), 286-319. https://doi.org/10.1108/JFMPC-07-2015-0028

58. McIvor, R. (2003). Outsourcing: insights from the telecommunications industry. Supply Chain Management: An International Journal, 8(4), 380-394. https://doi.org/10.1108/13598540310490134

59. McIvor, R. (2008). What is the right outsourcing strategy for your process? European Management Journal, 26(1), 24-34. https://doi.org/10.1016/j.emj.2007.08.008

60. McIvor, R. (2016). An analysis of the application of process improvement techniques in business process outsourcing. International Journal of Quality \& Reliability Management, 33(3), 321-343. https://doi.org/10.1108/IJQRM-04-2014-0045

61. McIvor, R. T., Humphreys, P. K., \& McAleer, W. E. (1997). A strategic model for the formulation of an effective make or buy decision. Management Decision, 35(2), 169-178. https://doi.org/10.1108/00251749710160331

62. Serrano, R. M., Ramírez, M. R. G., \& Gascó, J. L. G. (2018). Should we make or buy? An update and review. European Research on Management and Business Economics, 24(3), 137-148. https://doi.org/10.1016/j.iedeen.2018.05.004

63. Miceli, T. J., Sazama, G. W., \& Sirmans, C. F. (1994). The role of limited-equity cooperatives in providing affordable housing. Housing Policy Debate, 5(4), 469-490. https://doi.org/10.1080/10511482.1994.9521175

64. Moore, T. (2018). Replication through partnership: the evolution of partnerships between community land trusts and housing associations in England. International Journal of Housing Policy, 18(1), 82-102. https://doi.org/10.1080/14616718.2016.1198084

65. Morrison, N. (2016). Institutional logics and organisational hybridity: English housing associations' diversification into the private rented sector. Housing Studies, 31(8), 897-915. https://doi.org/10.1080/02673037.2016.1150428

66. Moschuris, S. J. (2007). Triggering mechanisms in make-or-buy decisions: An empirical analysis. Journal of Supply Chain Management, 43(1), 40-49. https://doi.org/10.1111/j.1745-493X.2007.00026.x

67. Muir, J., \& Mullins, D. (2015). The Governance of Mandated Partnerships: The Case of Social Housing 
Procurement. Housing Studies, 30(6), 967-986. https://doi.org/10.1080/02673037.2014.995070

68. Mullins, D., \& Moore, T. (2018). Self-organised and civil society participation in housing provision. International Journal of Housing Policy, 18(1), 1-14. https://doi.org/10.1080/19491247.2018.1422320

69. Negara, S. D. (2016). Indonesia's Infrastructure Development Under The Jokowi Administration. In Southeast Asian Affairs. https://doi.org/10.1355/9789814695671-013

70. Nilsson, F. R. (2019). A complexity perspective on logistics management. The International Journal of Logistics Management, 30(3), 681-698. https://doi.org/10.1108/IJLM-06-2019-0168

71. Nygaard, C., Berry, M., \& Gibb, K. (2008). The Political Economy of Social Housing Reform-A Framework for Considering Decentralised Ownership, Management and Service Delivery in Australia. Urban Policy and Research, 26(1), 5-21. https://doi.org/10.1080/08111140701540778

72. Obeidat, M. S., Qasim, T., \& Khanfar, A. (2018). Implementing the AHP multi-criteria decision approach in buying an apartment in Jordan. Journal of Property Research, 35(1), 53-71. https://doi.org/10.1080/09599916.2017.1413588

73. Palm, P. (2016). Information for decision-making in in-house and outsourced real estate management organisations. Facilities, 34(13/14), 891-905. https://doi.org/10.1108/F-05-2015-0034

74. Prajanti, S. D. W. (2014). Strategy for controlling agricultural land conversion of paddy by using analytical hierarchy process in Central Java. Management of Environmental Quality: An International Journal, 25(5), 631-647. https://doi.org/10.1108/MEQ-07-2013-0080

75. Prasad, K. V., Vasugi, V., Venkatesan, R., \& Bhat, N. S. (2019). Critical causes of time overrun in Indian construction projects and mitigation measures. International Journal of Construction Education and Research, 15(3), 216-238. https://doi.org/10.1080/15578771.2018.1499569

76. Qadri, R. A. (2019). Menakar model pembelian langsung rumah negara di Indonesia. Jurnal Pajak dan Keuangan Negara, 1(1), 1-20.

77. Qadri, R. A., Gunawan, E., \& Zikrulah, A. (2020). Emancipating Homo Pancasilaus principles for resolving obfuscation in designing residency provision policy. In A. Solikin, Y. Hadiwibowo, B. Setiawan, A. Firmansyah, \& H. D. Mulyaningsih (Eds.), Public Sector Accountants and Quantum Leap: How Far We Can Survive in Industrial Revolution 4.0? (First, pp. 1-5). https://doi.org/10.1201/9780367822965-20

78. Ray, D., \& Ing, L. Y. (2016). Addressing Indonesia's Infrastructure Deficit. Bulletin of Indonesian Economic Studies, 52(1), 1-25. https://doi.org/10.1080/00074918.2016.1162266

79. Roberts, K. (2012). The end of the long baby-boomer generation. Journal of Youth Studies, 15(4), $479-497$. https://doi.org/10.1080/13676261.2012.663900

80. Rohe, W. M. (1995). Converting public housing to cooperatives: The experience of three developments. Housing Policy Debate, 6(2), 439-479. https://doi.org/10.1080/10511482.1995.9521192

81. Roig-Tierno, N., Baviera-Puig, A., Buitrago-Vera, J., \& Mas-Verdu, F. (2013). The retail site location decision process using GIS and the analytical hierarchy process. Applied Geography, 40, 191-198. https://doi.org/10.1016/j.apgeog.2013.03.005

82. Rosile, G. A., Boje, D. M., Carlon, D. M., Downs, A., \& Saylors, R. (2013). Storytelling Diamond. Organizational Research Methods, 16(4), 557-580. https://doi.org/10.1177/1094428113482490

83. Ruonavaara, H. (2018). Theory of Housing, From Housing, About Housing. Housing, Theory and Society, 35(2), 178-192. https://doi.org/10.1080/14036096.2017.1347103

84. Russo, R. D. F. S. M., \& Camanho, R. (2015). Criteria in AHP: A Systematic Review of Literature. Procedia Computer Science, 55(Itqm), 1123-1132. https://doi.org/10.1016/j.procs.2015.07.081

85. Saaty, T. L. (1977). A scaling method for priorities in hierarchical structures. Journal of Mathematical Psychology, 15(3), 234-281. https://doi.org/10.1016/0022-2496(77)90033-5

86. Saaty, T. L. (1982). The Analytic Hierarchy Process: A New Approach to Deal with Fuzziness in Architecture. Architectural Science Review, 25(3), 64-69. https://doi.org/10.1080/00038628.1982.9696499

87. Saaty, T. L. (1990). How to make a decision: The analytic hierarchy process. European Journal of Operational Research, 48(1), 9-26. https://doi.org/10.1016/0377-2217(90)90057-I

88. Saaty, T. L. (2004). Decision making - the Analytic Hierarchy and Network Processes (AHP/ANP). Journal of Systems Science and Systems Engineering, 13(1), 1-35. https://doi.org/10.1007/s11518-006-0151-5

89. Saunders, M., Lewis, P., \& Thornhill, A. (2015). Research Methods for Business Students (Seventh). Pearson Education Ltd.

90. Schniederjans, M. J., Hoffman, J. J., \& Sirmans, G. S. (1995). Using Goal Programming and the analytic hierarchy process in house selection. The Journal of Real Estate Finance and Economics, 11(2), 167-176. https://doi.org/10.1007/BF01098660

91. Sillanpää, I. (2015). Strategic decision making model for make or buy decisions. International Journal of Logistics Economics and Globalisation, 6(3), 205. https://doi.org/10.1504/IJLEG.2015.073894

92. Smart, A. F. (2010). E-procurement and its impact on supply management - evidence from industrial case studies. International Journal of Logistics Research and Applications, 13(6), 423-440. https://doi.org/10.1080/13675567.2010.486760 
93. Stringfellow, A., Teagarden, M. B., \& Nie, W. (2008). Invisible costs in offshoring services work. Journal of Operations Management, 26(2), 164-179. https://doi.org/10.1016/j.jom.2007.02.009

94. Sun, Z., Pan, L., Wang, Y., \& Zhang, D. (2013). The Purchase House Choice Research Based on the Analytic Hierarchy Process (AHP). In The 19th International Conference on Industrial Engineering and Engineering Management (pp. 897-902). https://doi.org/10.1007/978-3-642-38391-5_95

95. Susilawati, \& Wirahadikusumah, R. D. (2006). Kajian Pengadaan oleh Kontraktor Pelaksana pada Proyek Konstruksi Bangunan Gedung. Jurnal Teknik Sipil, 13(3), 133-150.

96. Takamura, Y., \& Tone, K. (2003). A comparative site evaluation study for relocating Japanese government agencies out of Tokyo. Socio-Economic Planning Sciences, 37(2), 85-102. https://doi.org/10.1016/S0038$\underline{0121(02) 00049-6}$

97. Tayles, M., \& Drury, C. (2001). Moving from Make/Buy to Strategic Sourcing: The Outsource Decision Process. Long Range Planning, 34(5), 605-622. https://doi.org/10.1016/S0024-6301(01)00080-2

98. Teo, S. S. K. (2015). Rethinking graduated citizenship: Contemporary public housing in Singapore. Geoforum, 65, 222-231. https://doi.org/10.1016/j.geoforum.2015.08.003

99. Thaker, H. M. T., \& Sakaran, K. C. (2016). Prioritisation of key attributes influencing the decision to purchase a residential property in Malaysia. International Journal of Housing Markets and Analysis, 9(4), 446-467. https://doi.org/10.1108/IJHMA-09-2015-0052

100.Toor, S. U. R., \& Ogunlana, S. (2008). Problems causing delays in major construction projects in Thailand. Construction Management and Economics, 26(4), 395-408. https://doi.org/10.1080/01446190801905406

101.Udoyono, K. (2012). E-procurement dalam Pengadaan Barang dan Jasa untuk Mewujudkan Akuntabilitas di Kota Yogyakarta. Jurnal Studi Pemerintahan, 3(1), 135-171. https://doi.org/10.18196/jgp.2012.0008

102.Villena, V. H., Revilla, E., \& Choi, T. Y. (2011). The dark side of buyer-supplier relationships: A social capital perspective. Journal of Operations Management, 16(2011), 561-576. https://doi.org/10.1016/j.jom.2010.09.001

103. Walker, D. H. T., \& Vines, M. W. (2000). Australian multi-unit residential project construction time performance factors. Engineering Construction and Architectural Management, 7(3), 278-284. https://doi.org/10.1046/j.1365-232x.2000.00159.x

104.Walker, R. M. (2001). How to abolish public housing: Implications and lessons from public management reform. Housing Studies, 16(5), 675-697. https://doi.org/10.1080/02673030120080116

105. Wang, J. (2012). The developmental state in the global hegemony of neoliberalism: A new strategy for public housing in Singapore. Cities, 29(6), 369-378. https://doi.org/10.1016/j.cities.2011.11.004

106. Warburton, E. (2016). Jokowi and the New Developmentalism. Bulletin of Indonesian Economic Studies, 52(3), 297-320. https://doi.org/10.1080/00074918.2016.1249262

107.Wu, F. (2010). Housing environment preference of young consumers in Guangzhou, China. Property Management, 28(3), 174-192. https://doi.org/10.1108/02637471011051318

108. Yap, J. Y. L., Ho, C. C., \& Ting, C.-Y. (2019). A systematic review of the applications of multi-criteria decision-making methods in site selection problems. Built Environment Project and Asset Management, 9(4), 548-563. https://doi.org/10.1108/BEPAM-05-2018-0078

109.Zidane, Y. J. T., \& Andersen, B. (2018). The top 10 universal delay factors in construction projects. International Journal of Managing Projects in Business, 11(3), 650-672. https://doi.org/10.1108/IJMPB-052017-0052

110.Zukhrina-Oktaviani, C. (2015). Hubungan Antara Kualitas Pengadaan Pekerjaan Konstruksi Pemerintah Dengan Kualitas Infrastruktur Indonesia. Seminar Nasional Teknik Sipil V Tahun 2015, 86(71), $286-291$. 